\title{
A small nucleolar RNA is processed from an intron of the human gene encoding ribosomal protein $\mathrm{S} 3$
}

\author{
Kazimierz Tyc Tycowski, Mei-Di Shu, and Joan A. Steitz \\ Department of Molecular Biophysics and Biochemistry, Howard Hughes Medical Institute, Yale University School \\ of Medicine, New Haven, Connecticut 06536-0812 USA
}

\begin{abstract}
A human small nucleolar RNA, identified previously in HeLa cells by anti-fibrillarin autoantibody precipitation and termed RNA X, has been characterized. It comprises two uridine-rich variants (148 and 146 nucleotides), which we refer to as snRNA U15A and U15B. Secondary structure models predict for both variants a U15-specific stem-loop structure, as well as a new structural motif that contains conserved sequences and can also be recognized in the other fibrillarin-associated nucleolar snRNAs, U3, U14, and RNA Y. The single-copy gene for human U15A has been found unexpectedly to reside in intron 1 of the ribosomal protein S3 gene; the U15A sequence appears on the same strand as the S3 mRNA and does not exhibit canonical transcription signals for nuclear RNA polymerases. U15A RNA is processed in vitro from S3 intron 1 transcripts to yield the correct $5^{\prime}$ end with a $5^{\prime}$-monophosphate; the in vitro system requires ATP for $3^{\prime}$ cleavage, which occurs a few nucleotides downstream of the mature end. The production of a single primary transcript specifying the mRNA for a ribosomal or nucleolar protein and a nucleolar snRNA may constitute a general mechanism for balancing the levels of nucleolar components in vertebrate cells.
\end{abstract}

[Key Words: U15 snRNA; ribosomal protein S3; nucleolus; RNA processing; intron]

Received April 1, 1993; revised version accepted May 4, 1993.

Nuclei of all types of eukaryotic cells contain small ribonucleoproteins (snRNPs), each composed of a short RNA and several different proteins (for review, see Lührmann 1988; Reddy and Busch 1988). One class of mammalian snRNPs includes U3, U8, U13, and U14 and is found in nucleoli (Reddy et al. 1979; Tyc and Steitz 1989; Liu and Maxwell 1990). These particles are precipitable by autoantibodies from scleroderma patients directed against fibrillarin, an abundant $34-\mathrm{kD}$ protein of the fibrillar region of the nucleolus (Lischwe et al. 1985; Ochs et al. 1985). U3, U8, and U13 RNAs possess $\mathrm{m}_{3} \mathrm{G}$ caps at their $5^{\prime}$ ends, whereas the $5^{\prime}$ terminus of U14 is unblocked (Maxwell and Martin 1986). The U3 snRNP has been found in all organisms and has recently been shown in mouse, Xenopus, and yeast to function in rRNA processing (Kass et al. 1990; Savino and Gerbi 1990; Hughes and Ares 1991). U14 snRNA has been characterized in yeast cells [originally designated snR 128 (Zagorski et al. 1988)] where genetic analyses show it to be required for proper maturation of $18 \mathrm{~S}$ rRNA ( $\mathrm{Li}$ et al. 1990). Anti-fibrillarin antibodies precipitate additional small RNAs from human cells, among them RNAs X and Y (Tyc and Steitz 1989).

Most mammalian snRNAs are encoded by multicopy gene families that include a large number of untranscribed snRNA pseudogenes (for review, see Dahlberg and Lund 1988). The $\mathrm{m}_{3} \mathrm{G}$-capped snRNAs are synthe- sized by RNA polymerase II (pol II) directed by promoter and termination signals that are distinct from those normally found in protein-coding genes (for review, see Dahlberg and Lund 1988). The genes encoding $\gamma$-monophosphate-capped and uncapped snRNAs, which are synthesized by RNA pol III, also contain unusual promoter elements not found in other pol III-transcribed genes (for review, see Kunkel 1991).

A perfect DNA copy of the mouse U14 RNA sequence was found unexpectedly in intron 5 of the heat shock cognate 70 ( $h s c 70$ ) gene (Liu and Maxwell 1990), with two additional copies of U14-like sequences in other introns of the same gene. This intriguing organization of U14 genes within the hsc70 gene is conserved in other mammalian species (Liu and Maxwell 1990). Because the intron 5 gene does not possess recognizable transcription signals utilized by eukaryotic RNA polymerases, mammalian U14 RNA has been proposed either to be transcribed from a unique promoter or, alternatively, to be produced by the processing of the hsc70 introns (Liu and Maxwell 1990). The latter possibility has recently gained some experimental support. Mouse U14 RNA is excised from intron transcripts in Xenopus oocytes (Leverette et al. 1992).

Here, we report that the single gene for one of two variants of human RNA $X$, which we now refer to as U15A snRNA, resides in intron 1 of the gene encoding 
ribosomal protein (r-protein) S3. We have devised a cellfree system capable of excising U15A RNA from intron transcripts, arguing that it is normally processed from S3 pre-mRNA. The processing occurs within a secondary structure context that is common to several fibrillarinassociated nucleolar snRNAs.

\section{Results}

Structures of U15A and U15B RNAs reveal a motif shared by other nucleolar snRNAs

We observed previously that several small RNAs immunoprecipitated from HeLa cell sonicates with anti-fibrillarin antibodies do not contain $\mathrm{m}_{3} \mathrm{G}$ caps at their $5^{\prime}$ ends (Tyc and Steitz 1989). Partial sequence analysis of the $3^{\prime}$ ends of two of these RNAs, called $X$ and $Y$, revealed the presence of conserved box D sequences, which are common to all metazoan, anti-fibrillarin-precipitable, nucle- olar snRNAs (Tyc and Steitz 1989 and references therein). We completed sequence analysis of RNA X by use of both digestion of the RNA with base-specific ribonucleases (Donis-Keller et al. 1977; Donis-Keller 1980) and chemical degradation of its cDNA (Maxam and Gilbert 1977). Enzymatic sequencing of 3'-end-labeled RNA X allowed the design of deoxyoligonucleotide U15$3^{\prime}$, complementary to 17 nucleotides at the $3^{\prime}$ terminus of RNA X (see Materials and methods). Primer extension from total cellular RNA using this oligonucleotide yielded two cDNAs of similar abundance that could be separated only on long $8-10 \%$ denaturing polyacrylamide gels (data not shown). The nucleotide sequences of both cDNAs were elucidated by chemical degradation (Maxam and Gilbert 1977), revealing two distinct 148and 146-nucleotide-long RNAs (Fig. 1A). The two RNA $\mathrm{X}$ variants, referred to as $\mathrm{U} 15 \mathrm{~A}$ and $\mathrm{U} 15 \mathrm{~B}$, are uridine rich with $28.5 \%$ and $30 \%$ uridine content, respectively. They represent novel snRNA species lacking significant

A
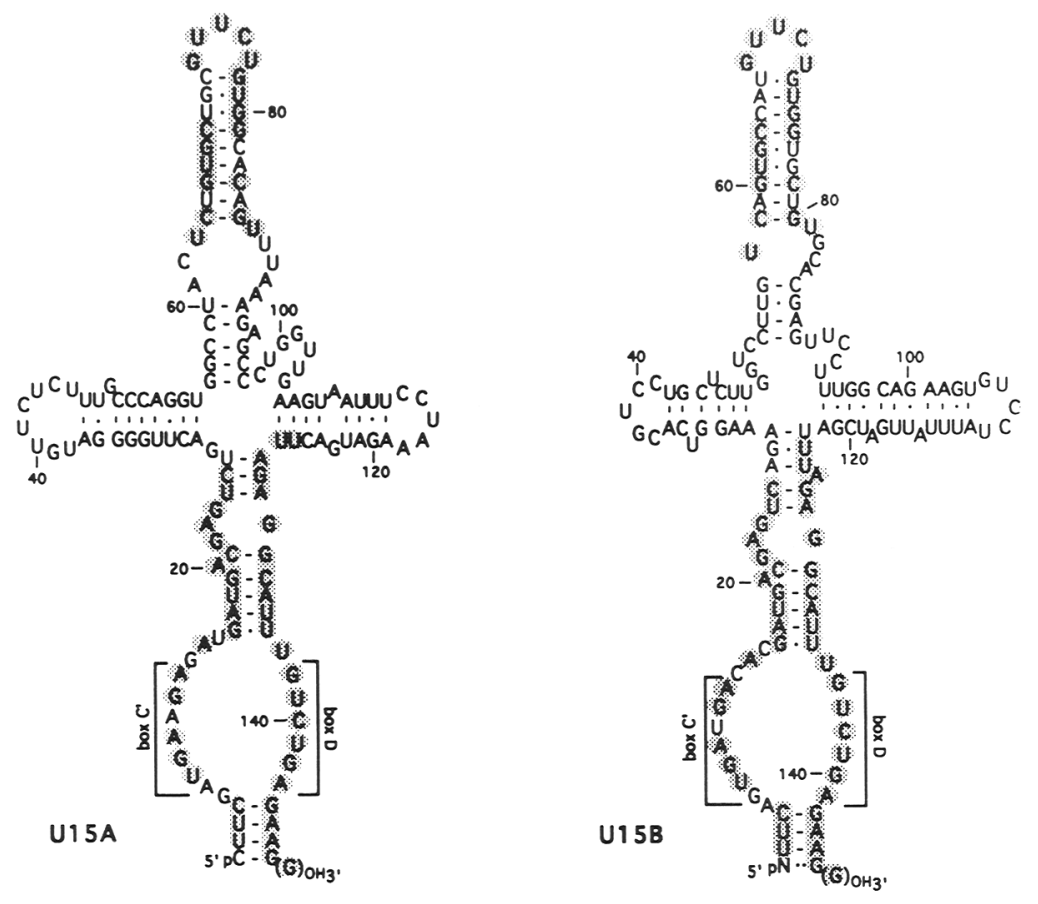

B

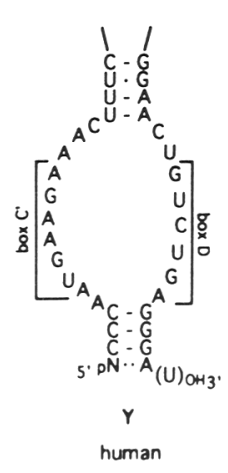

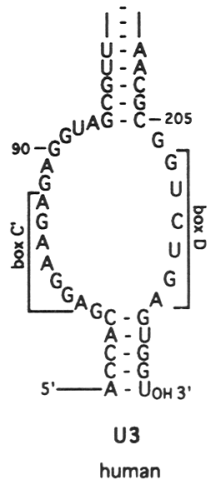

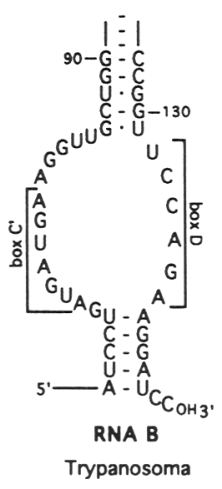

Figure 1. (A) Primary and possible secondary structures of human U15A and U15B RNAs. The secondary structures were generated with the help of the Fold and StemLoop Programs of the GCG, University of Wisconsin. The nucleotides conserved between A and B variants are shaded. $(B)$ The secondary structures of the stem/loop/stem motif in RNA Y, U14, U3, and Trypanosoma brucei RNA B, a putative U3 homolog (Hartshorne and Agabian 1993). The 3'-terminal nucleotides shown in parentheses are missing in some populations of both U15A RNAs and RNA Y. Conserved boxes $\mathrm{C}^{\prime}$ and $\mathrm{D}$ are marked. The sequences of $\mathrm{U} 3$ and U14 are from Parker and Steitz (1987) and Liu and Maxwell (1990), respectively. 
homology to any known RNA. U15A and U15B exhibit $65 \%$ overall sequence identity with three highly conserved regions appearing at the ends and in the middle of the molecules (Fig. 1A).

Computer modeling was used to generate secondary structures for U15A and U15B RNAs (Fig. 1A). These models predict that the $5^{\prime}$ and $3^{\prime}$ termini of both RNAs form a 4-bp stem followed by an extensive internal loop closed by another stem. This stem/loop/stem motif includes the terminal conserved regions of the two U15 variants and can also be found in mouse U14, human RNA Y [whose nucleotide sequence is only partially determined (K.T. Tycowski, M.-D. Shu, and J.A. Steitz, unpubl.|], and all known U3 RNAs (Fig. 1B). Even Trypanosoma RNA B, a putative U3 homolog (Hartshorne and Agabian 1993) whose primary structure is most highly diverged from other U3 RNAs, can be folded into a similar structure (Fig. 1B). In every case, the $3^{\prime}$ strand of the internal loop contains the conserved sequence defined earlier in U3, U8, U13 and U14 as box D (Hughes et al. 1987; Tyc and Steitz 1989; Jarmolowski et al. 1990). The $5^{\prime}$ side of the loop harbors a sequence PuUGA ${ }^{\mathrm{A}} / \mathrm{UGA}$ that resembles box C of U3, U8, and U13 RNAs (Hughes et al. 1987; Tyc and Steitz 1989). But because this sequence appears in $\mathrm{U} 3$ in addition to a canonical box $\mathrm{C}$ [UGAUGAUPyG, human U3 positions 158-166 (Tyc and Steitz 1989)], we designate it box $\mathrm{C}^{\prime}$. Other nucleotides in the internal loop as well as those involved in the flanking stems are not conserved. Note that the position of boxes $\mathrm{C}^{\prime}$ and $\mathrm{D}$ is always constant relative to the terminal stem (Fig. 1).

The third conserved region of U15 RNA folds into a hairpin structure that is shared only by U15A and U15B (Fig. 1A, top stem-loop). Note that there is one compensatory base pair change in the stem of this structure (nucleotides $65 / 85$ and 59/79 in the A and B variant, respectively) and that other changes in the stem do not disrupt base-pairing.

\section{Both U15 and RNA Y have monophosphate groups at their $5^{\prime}$ ends}

Because the U15 RNAs and RNA Y are not precipitable by anti- $\mathrm{m}_{3} \mathrm{G}$ antibody (Tyc and Steitz 1989), they were suspected to possess either alternative cap structures or unblocked $5^{\prime}$ ends. Direct determination of their $5^{\prime}$ end structures from in vivo-labeled HeLa RNA proved difficult because of the low abundance $\left(\sim 1-3 \times 10^{4}\right.$ copies per cell) of these species. Instead, we asked whether their $5^{\prime}$ termini could be labeled by polynucleotide kinase. Total anti-fibrillarin-precipitated RNAs were incubated with $\left[\gamma^{-32} \mathrm{P}\right] \mathrm{ATP}$ and kinase either directly (Fig. 2A, lane 4) or after prior treatment with alkaline phosphatase (lane 5). Both U15 variants (lanes 6,7), U15A alone (lanes 8,9 ), U15B alone (lanes 10,11), or RNA Y (lanes 12,13) were then affinity selected with biotinylated deoxyoligonucleotides U15-3', U15A(91-110), U15B(28-44), or $\mathrm{Y}-3^{\prime}$, respectively, and streptavidin-agarose. (Because oligonucleotide U15-3' is complementary to a common sequence in the U15A and B variants, it selects both
RNAs.) Uniformly labeled human U6 snRNA (lane 1) was added as a control for recovery and was coselected using biotinylated 2'-O-methyl RNA oligonucleotide U6d (lanes 6-13). U15A (lanes 7,9), U15B (lanes 7,11), and RNA Y (lane 13) become labeled at their $5^{\prime}$ ends after prior dephosphorylation but not when the phosphatase treatment is omitted (lanes $6,8,10,12)$. We conclude that the 5' termini of both U15 variants and RNA Y possess at least one phosphate group and that the same is true for some other anti-fibrillarin-precipitable RNAs (cf. lane 4 with lane 5). 5'-End labeling reproducibly reveals a more heterogenous population of U15 RNAs compared with the 3' labeling procedure (cf. lane 7 with lane 4). This is most likely attributable to nonspecific degradation of U15 at the $3^{\prime}$ end either during extract preparation or during labeling. (RNA $3^{\prime}$ ends produced by nonspecific degradation are usually not labeled, because they possess $3^{\prime}$-monophosphates). In addition to the major U15B species, the U15B-specific oligonucleotide reproducibly selects a shorter RNA (lane 11), which may represent a U15B subvariant because a band of corresponding size is also visible in the $3^{\prime}$-end labeled anti-fibrillarin-precipitated RNA (lane 3).

To determine the number of phosphate groups at the $5^{\prime}$ ends of U15 and RNA Y, we used $\left[\alpha^{-32}\right.$ P]GTP and guanylyltransferase from vaccinia virus, which transfers labeled GDP from $\left[\alpha^{-32} \mathrm{P}\right]$ GTP to the $5^{\prime}$ terminus of an RNA containing a $5^{\prime}$ tri- or diphosphate (Shuman and Moss 1990). As seen in Figure 2B (lane 4) neither U15 nor RNA Y becomes detectably labeled (they are not visible even after prolonged exposure of the gel). As controls, $5 \mathrm{~S}$ rRNA, known to possess predominantly $5^{\prime}-\mathrm{di}^{-}$and triphosphates (Hatlen et al. 1969), is labeled by guanylyltransferase (lanes 3,4 ), whereas 5.8S rRNA, tRNA, U3, and U8, all of which possess either $5^{\prime}$-monophosphates or $5^{\prime}$-caps, are not labeled by this procedure (lanes 3,4 ). This result, together with the requirement for dephosphorylation before 5 -end labeling by polynucleotide kinase, strongly suggests that U15A, U15B, and RNA Y all contain monophosphates at their $5^{\prime}$ termini.

\section{U15 and Y RNAs are localized to the cell nucleolus}

Immunoprecipitation by anti-fibrillarin antibodies suggested that both U15 and Y RNAs reside in the nucleolus. To confirm this assumption, we fractionated HeLa cells into cytoplasmic and nuclear fractions, and subsequently separated the nuclei into nucleoplasm and nucleoli. RNAs isolated from each fraction were probed by reverse transcription with oligonucleotides U15-3' (for both U15A and B) and Y-3' (for RNA Y) as primers (Fig. 3). As controls, each fraction was also assessed for the presence of a known nucleolar RNA, by use of a U3/6479) oligonucleotide, and a known nucleoplasmic RNA, by use of a U2(28-42) oligonucleotide, as primers. Under the hypotonic conditions used, U15 and RNA Y are retained in the nuclear fraction more efficiently than U2 (cf. lane 2 with 3). Subfractionation of the nuclei shows clearly that U15 and Y are recovered with U3 predominantly in the nucleolar pellet (lane 5), whereas U2 frac- 


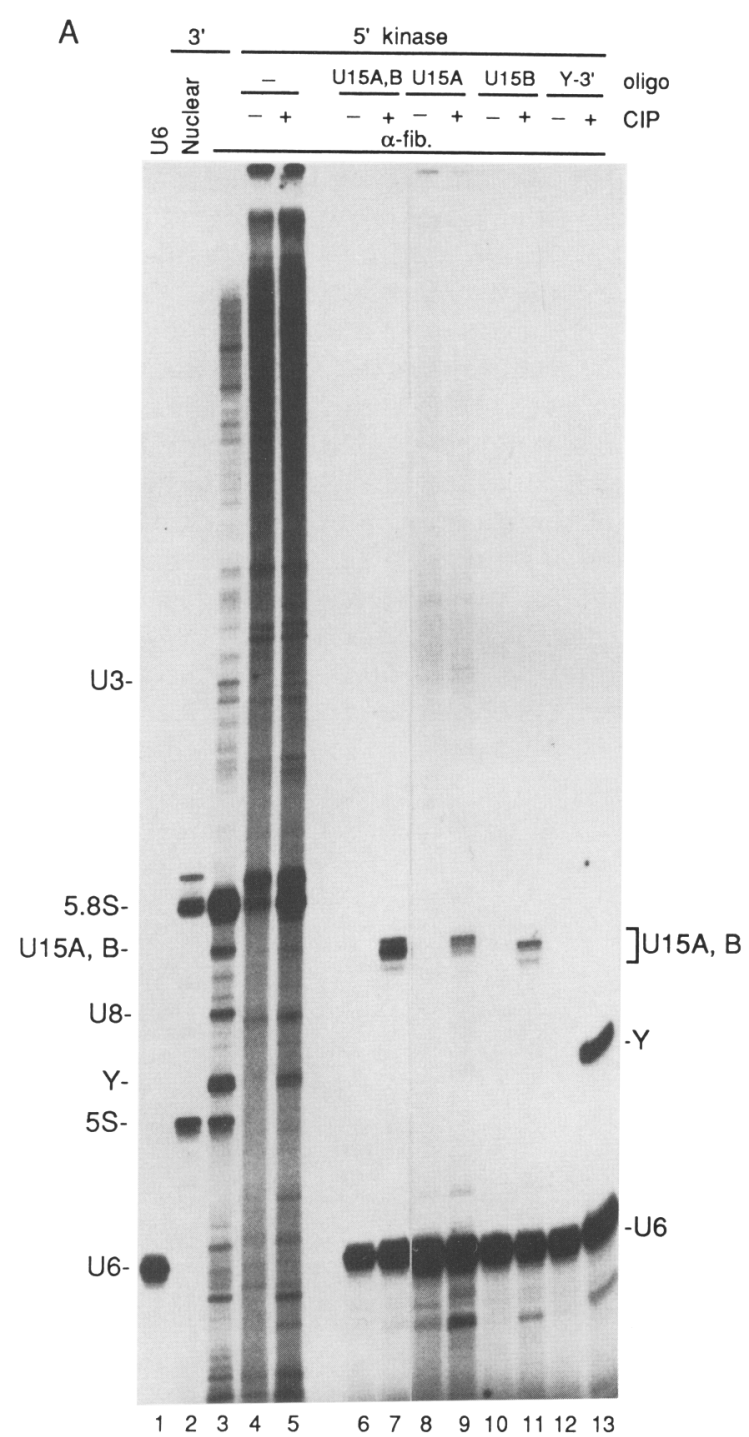

tionates with the nucleoplasm (lane 4). We conclude that both U15 and Y RNAs are nucleolar snRNAs.

\section{Cloning of the single U15A RNA gene}

Southern blot analysis of HeLa cell genomic DNA digested with several restriction endonucleases (Fig. 4) revealed single fragments of $>7200 \mathrm{bp}(B g I \mathrm{II}), \sim 1800 \mathrm{bp}$ (PstI), $\sim 1650$ bp (PstI + EcoRI), and $\sim 950 \mathrm{bp}$ (PstI + NsiI and HpaII) that hybridize to a DNA probe spanning nucleotides $30-125$ of U15A RNA. This sequence excludes both terminal conserved regions and therefore should be specific for the U15A gene. Subsequent hybridization of the Southern blot of Figure 4 with a DNA probe containing nucleotides $30-120$ of the U15B gene likewise showed single fragments but of different sizes from those obtained with the U15A probe (data not shown). These results suggested that both $\mathrm{U15A}$ and $\mathrm{B}$ are encoded by single-copy genes that are not adjacent in the human genome.

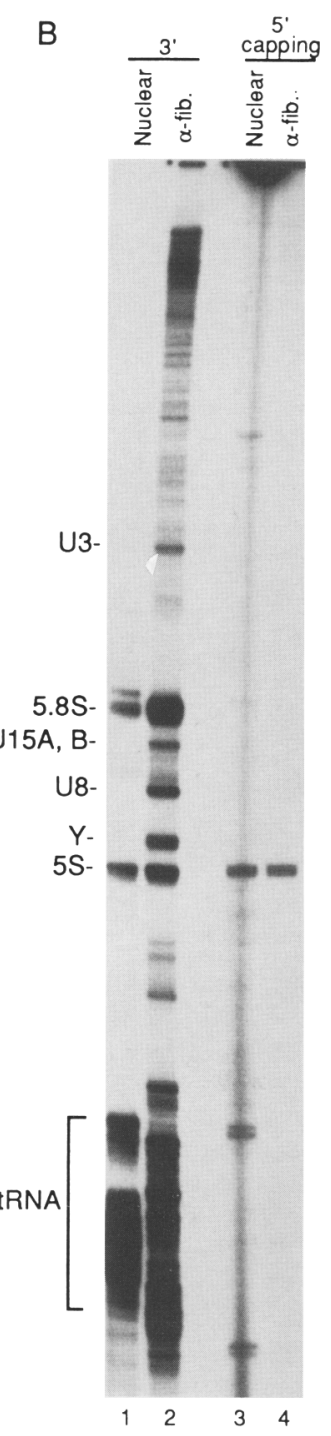

Figure 2. Analysis of $5^{\prime}$-end structures in U15 and Y RNAs. (A) HeLa cell RNA obtained by anti-fibrillarin precipitation of a cell sonicate prepared in $0.5 \mathrm{M} \mathrm{NaCl}$ was labeled with $\left[\gamma^{-32} \mathrm{P}\right] \mathrm{ATP}$ and polynucleotide kinase either directly (lane 4) or with prior dephosphorylation (lane 5). RNAs selected with streptavidin-agarose and a biotinylated U15A and B-specific deoxyoligonucleotide U15-3' (lanes $6,7)$, a U15A-specific deoxyoligonucleotide U15A(91-110) (lanes 8,9), a U15B-specific deoxyoligonucleotide U15B/28-44) (lanes 10,11 , or an RNA Y-specific deoxyoligonucleotide Y-3' (lanes 12,13) were fractionated on an $8 \%$ denaturing polyacrylamide gel. Uniformly labeled human U6 RNA was included as an internal control and was coselected with a 2'-O-methyl RNA oligonucleotide (lanes 6-13). (Lane 1) One-third the amount of U6 used in lanes 6-13. (Lanes 2,3) 3'-End labeled total nuclear RNA from $1.5 \times 10^{4}$ cells and anti-fibrillarin precipitated RNA from $3.5 \times 10^{5}$ cells, respectively. Lanes 4 and 5 , lanes $6-11$, and lanes 12 and 13 represent RNA from $2 \times 10^{5}, 7.5 \times 10^{6}$, and $2.5 \times 10^{6}$ cells, respectively. $(B)$ HeLa cell RNA precipitated from a sonicate prepared in $0.5 \mathrm{M} \mathrm{NaCl}$ was mixed with an equal amount of RNA precipitated from a $250 \mathrm{mM} \mathrm{NaCl}$ sonicate to increase the level of $5 \mathrm{~S}$ rRNA, which served as a positive control in this experiment. The anti-fibrillarin-precipitated RNA mixture from $7.5 \times 10^{6}$ cells (lane 4) and total nuclear RNA from $4 \times 10^{5}$ cells (lane 3 ) were labeled with $\left[\alpha^{-32} \mathrm{P}\right] \mathrm{GTP}$ and guanylyltransferase from vaccinia virus. $3^{\prime}$-End labeled total nuclear RNA from $3 \times 10^{3}$ cells (lane 1) and the anti-fibrillarin-precipitated RNA mixture from $6 \times 10^{4}$ cells (lane 2) were run as markers. RNAs were fractionated on an $8 \%$ denaturing polyacrylamide gel.
Because we knew the U15A RNA sequence, we isolated sequences flanking the U15A RNA gene by inverted PCR amplification (Triglia et al. 1988). HeLa cell DNA was digested with either AluI, RsaI, or ApaLI (whose sites are absent from the U15A-coding sequence). The resulting restriction fragments were circularized with DNA ligase and, either directly or after subsequent digestion with DraI or BanII /whose sites are present within U15A), used for PCR amplification with primers X-15 and X-16 (see Fig. 5). Because correctly initiated PCR products were expected to contain both the 5 ' - and 3 '-terminal sequences of U15A, the amplified DNA was checked by Southern blot analysis with oligonucleotide U15A(28-44) (see Fig. 5) as a probe. Amplification of the DNA samples cut with AluI in each case resulted in a single abundant product of $\sim 400 \mathrm{bp}$, which hybridized to the U15A(28-44) oligonucleotide, whereas the sample digested with $R s a$ I yielded an $\sim 1600$-bp hybridizationpositive product only when amplification was carried out on circular DNA (data not shown). Both products 


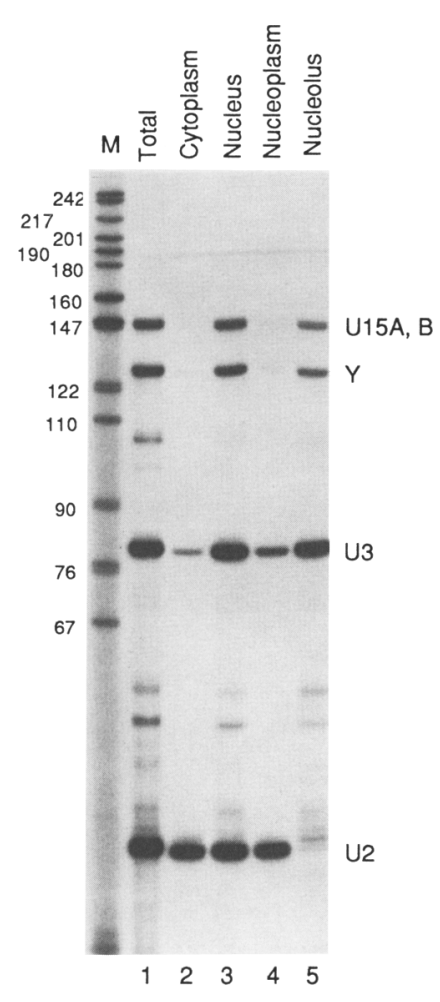

Figure 3. Subcellular localization of U15 and Y RNAs. HeLa cells were fractionated into cytoplasmic and nuclear fractions, and the resulting nuclei were subfractionated further into nucleoplasm and nucleoli. RNA was isolated from each fraction and assayed for U15 and RNA Y by reverse transcription using $5^{\prime}$-end-labeled U15-3' and Y-3' primers, respectively, with U3 (nucleolar) and U2 (nucleoplasmic) RNAs serving as controls. RNA from $5 \times 10^{6}$ cells and an equimolar mixture of the four primers were used in each lane. The specific activity of the $\mathrm{U} 2(28-42)$ and $U 3(64-79)$ primers was five times lower than that of U15-3' and Y-3'. Reverse transcription products were fractionated on a $7 \%$ denaturing polyacrylamide gel. Cell fractions are indicated at the top. The sizes of DNA markers (M) are given at left.

were cloned into the pGEM $3 Z$ vector, and the resulting plasmids pU15A-AluI and pU15A-RsaI were sequenced (Fig. 5).

Inspection of the sequences (Fig. 5) revealed that the AluI fragment partially overlaps the RsaI fragment and that both contain a portion of the cDNA sequence reported for human r-protein S3 (Zhang et al.1990). An internal portion of the S3-coding region begins $155 \mathrm{nu}$ cleotides downstream from the $3^{\prime}$-end of the U15A sequence, suggesting that the gene for U15A is located within an intron of the $\mathrm{S} 3$ gene. We therefore produced a PCR clone containing the entire putative intron using S3-51 and S3-47 primers (see Fig. 5). Sequence analysis of this clone confirmed the presence of a 148-nucleotide region that corresponds exactly to the U15A RNA sequence within what appears to be the first intron interrupting the S3-coding region (Fig. 5). The sequences of the second and a part of the third intron, as well as of the second and the third exons, were determined by analyzing the pU15A-RsaI clone. To complete analysis of the third intron, another PCR clone was generated with the X-15 and S3-38 primers. In total, we determined $\sim 2800$ nucleotides of the human S3 gene, including the $3^{\prime}$ end of the first exon, exon 2, and exon 3 and the $5^{\prime}$ end of exon 4, as well as the three introns separating these exons (Fig. 5). The exon sequences are identical to the previously published sequence of a human $\mathrm{S} 3 \mathrm{cDNA}$ (Zhang et al. 1990). The second and the third introns do not contain sequences related to U15A or U15B RNA.

The portion of the $\mathrm{S} 3$ gene whose sequence has been established (Fig. 5) contains sites for all of the restriction enzymes used in the genomic Southern analysis of Figure 4, except BglII. The lengths of the restriction fragments that hybridize to the U15A probe (Fig. 4) correspond to those calculated from the S3 sequence obtained. These results argue strongly that the only sequence in the human genome encoding U15A RNA resides within intron 1 of the $\mathrm{S} 3$ gene (Fig. 5).

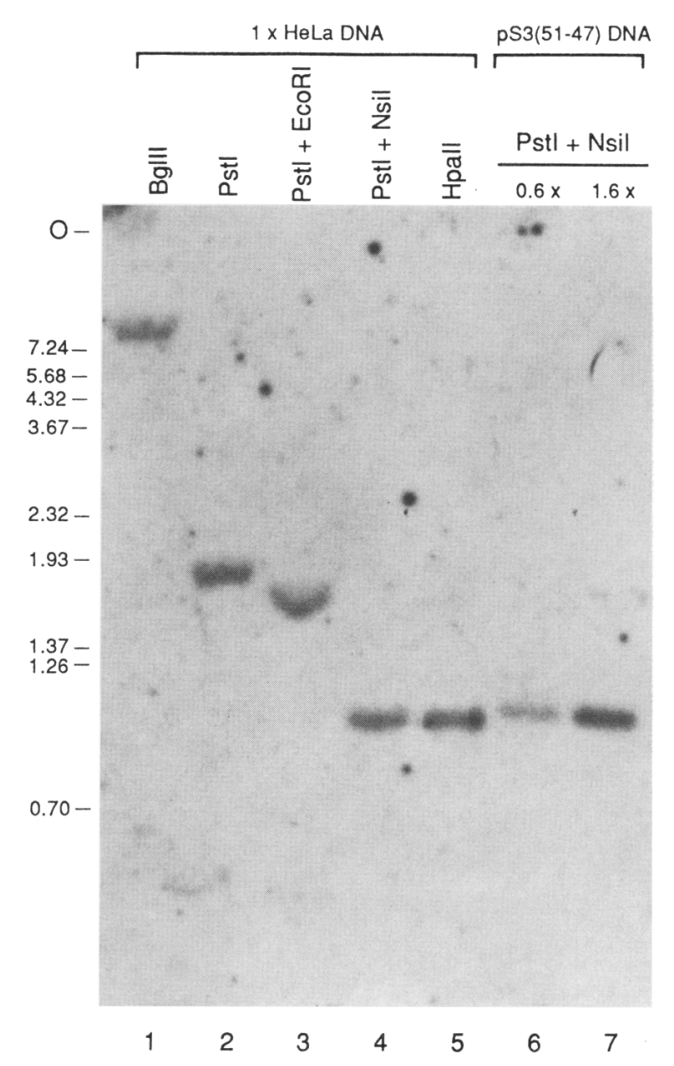

Figure 4. Hybridization analysis of genomic DNA. Restriction digests of $30 \mu \mathrm{g}$ of HeLa cell DNA (lanes 1-5) or $26 \mathrm{pg}$ (lane 6) and $65 \mathrm{pg}$ (lane 7$)$ of plasmid pS3(51-47) DNA were fractionated in a $0.9 \%$ agarose gel and transferred to a nitrocellulose membrane. The filter was hybridized with a DNA probe spanning nucleotides 30-125 of U15A RNA. Restriction enzymes used are indicated at the top, and the positions of $\lambda$ DNA fragments (sizes in kilobases) obtained by BstEII digestion are indicated at left. The numbers at the top indicate copy number equivalents of haploid human genome. 


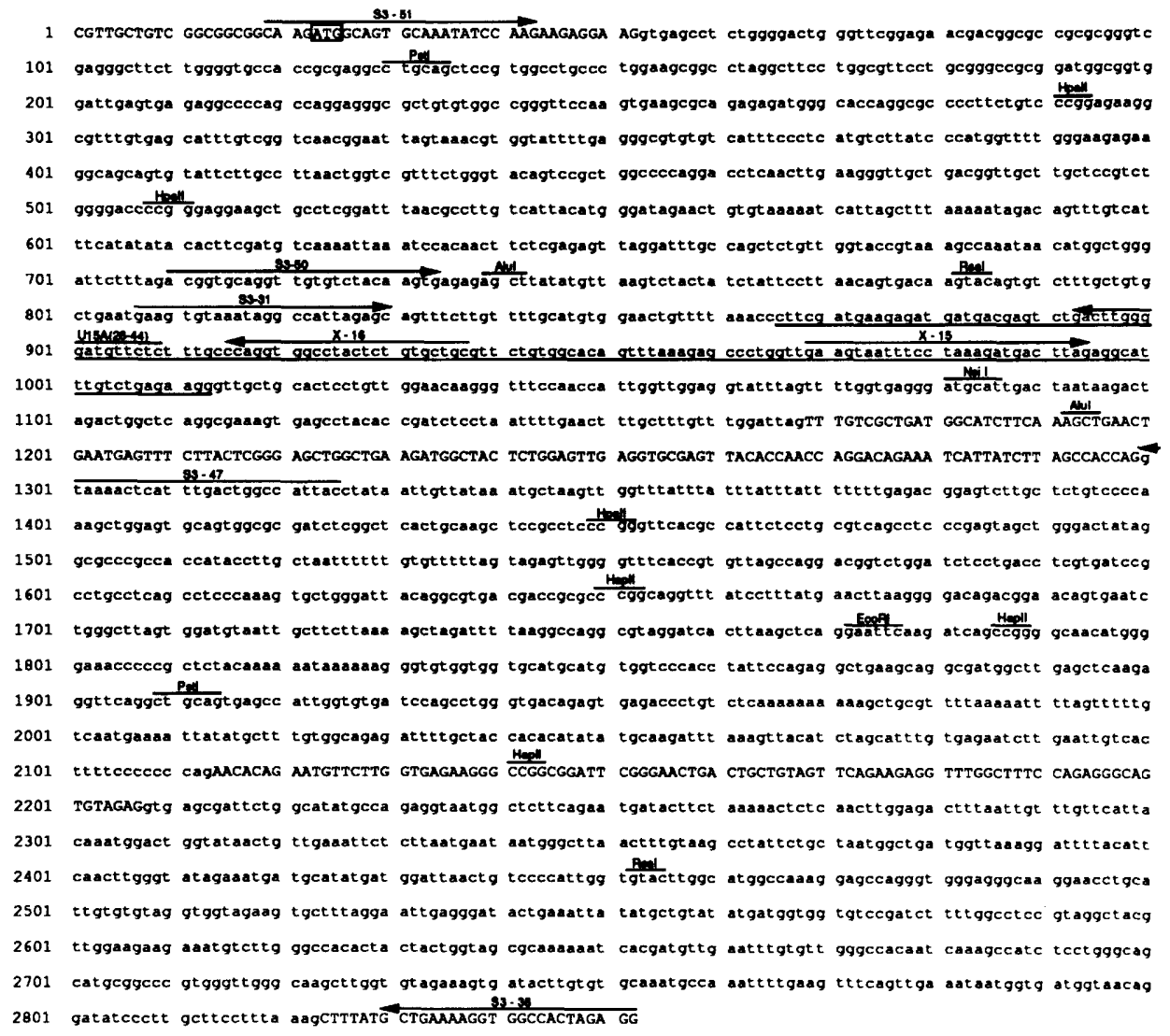

Figure 5. Nucleotide sequence of the $5^{\prime}$ portion of the human r-protein S3 gene. Exon and intron sequences are shown in uppercase and lowercase letters, respectively. The sequence that encodes U15A RNA is underlined. The initiation codon for protein S3 is boxed. Restriction sites for enzymes used for genomic hybridization (PstI, EcoRI, NsiI, and HpaII), as well as primers used for PCR amplification, are indicated. The AluI and RsaI sites shown were utilized to produce templates for inverted PCR amplification to obtain the pU15A-AluI and pU15A-RsaI clones. Exon 1 sequences $5^{\prime}$ to and covered by primer S3-51, as well as exon 4 sequences covered by primer S3-36, are taken from Zhang et al. (1990).

To determine the copy number of U15A RNA gene in the HeLa genome, we compared the intensity of the hybridization signal of HeLa DNA to that obtained from hybridization of the plasmid pS3(51-47) (4050 nucleotides long), which contains a single copy of the U15A gene (Fig. 4, cf. lanes 1-5 with 6 and 7). Quantitative analysis revealed that the ratio of the intensities of the hybridization signals of $30 \mu \mathrm{g}$ of HeLa DNA compared with $40 \mathrm{pg}$ of $\mathrm{pS} 3(51-47)$ DNA equals $1.4: 1$. Assuming that the haploid HeLa genome contains $\sim 3 \times 10^{9}$ nucleotides, this analysis further supports the notion that U15A RNA is encoded by a single gene.

\section{U15A RNA is excised from S3 intron transcripts in cell-free extracts}

Inspection of the U15A RNA gene and its flanking sequences did not reveal known transcription signals recognized by any nuclear eukaryotic RNA polymerase. This plus the fact that U15A contains a $5^{\prime}$-monophosphate indicated that U15A RNA might be generated by the processing of a longer transcript.

To test for the processing of U15A, we incubated in vitro-synthesized transcripts containing U15A and various lengths of flanking $5^{\prime}$ and $3^{\prime}$ sequences in several human and mouse cell extracts (Fig. 6; data not shown). These included HeLa cell nuclear (splicing) and cytoplasmic S-100 extracts, both prepared according to Dignam et al. (1983), as well as human HeLa and Raji cell and mouse L1210 cell S-100 whole-cell extracts, prepared according to Miller and Sollner-Webb (1981). Every substrate analyzed (the longest, $-847 /+460$, and the shortest $-59 /+220$, where +1 denotes the first nucleotide of U15A RNA) yielded three discrete products only after incubation in S-100 whole-cell extracts (Fig. 6; data not shown). We chose mouse L1210 extracts for further studies because they were the most active and produced the lowest background (data not shown).

Figure 6 shows characteristics of the processing of the $-156 /+220$ (lanes 1-18) and $-59 /+220$ (lanes 19-22) substrates in L1210 cell extract. Band C is only a few nucleotides longer than U15A RNA (cf. lane 22 with 23); hence, we call it U15A*. The lengths of the two longer products ( $A$ and $B$ ) suggested that they might contain U15A RNA plus the entire 5 -flanking sequence $(A)$ or the entire $3^{\prime}$ trailer $(B)$. Products $A$ and $B$ appear very 
Figure 6. In vitro processing of U15A from intron transcripts. Internally labeled processing substrates spanning nucleotides $-156 /+220$ (lanes 10,16$)$ or $-59 /+220$ (lane 19) (+1 denotes first nucleotide of U15A RNA) of S3 intron 1 were incubated in L1210 cell S-100 extract under the conditions described in Materials and methods for the times indicated at the top (lanes 1-9). Samples shown in lanes 11-15, 17, 18, 20, 21 , and 22 were incubated for $60 \mathrm{~min}$. (Lanes $12,17,20,22)$ Incubation under standard conditions; (lane 11) S-100 extract omitted from the reaction; (lanes 18,21) ATP omitted from the reaction; (lanes 13,14$) 4 \mathrm{~mm}$ and 2 mM EDTA, respectively, added to the reaction; (lane 15) $\mathrm{MgCl}_{2}$ increased to $3.25 \mathrm{~mm}$; (lane 23) 5'-end-labeled endogenous HeLa U15A. RNA was isolated from each reaction and fractionated on a $7 \%$ denaturing polyacrylamide gel. Processing products A, B, and $C\left(\mathrm{U} 15 \mathrm{~A}^{*}\right)$ are indicated. The sizes of DNA markers $(\mathrm{M})$ are shown.

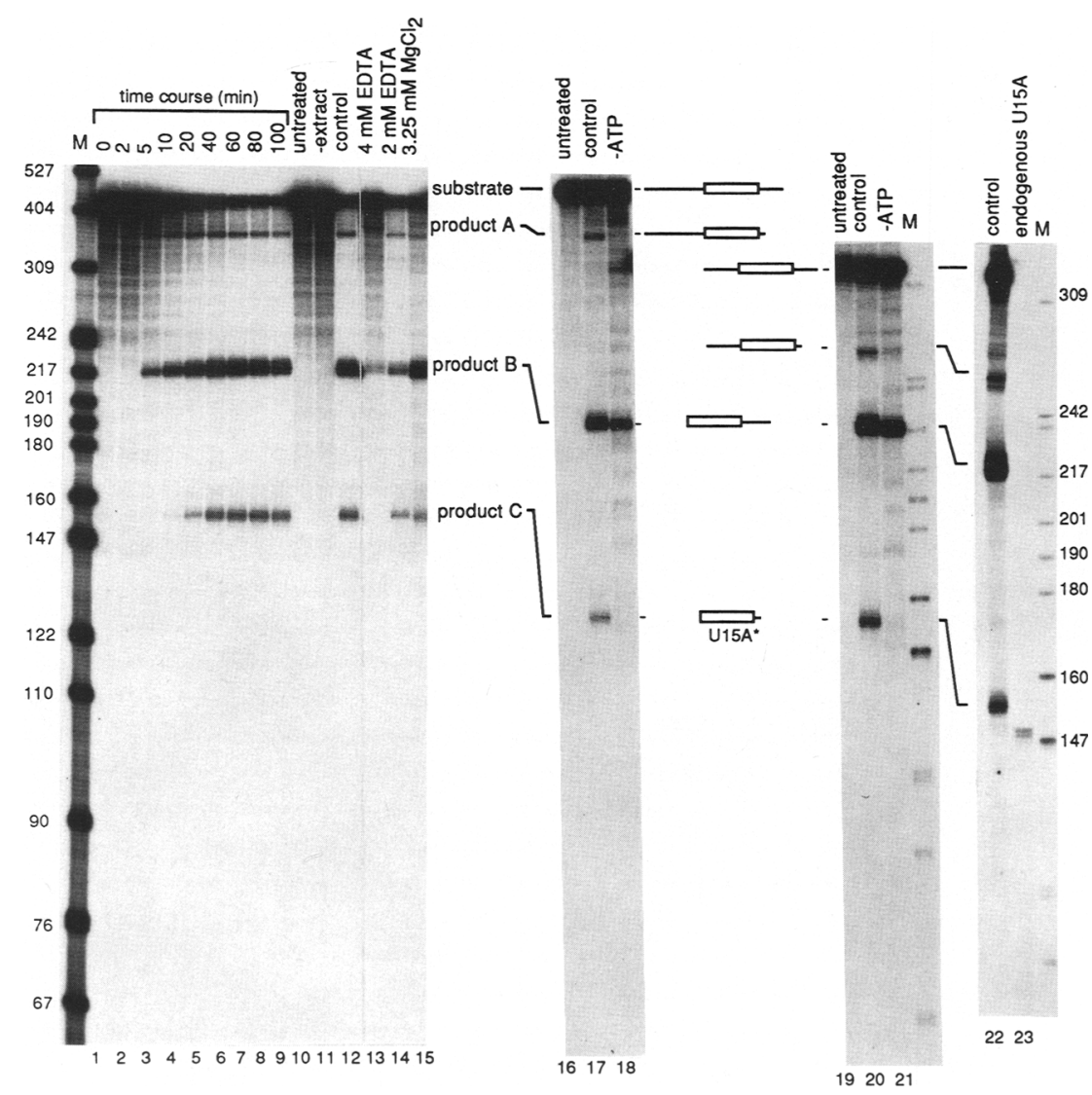

rapidly (Fig. 6, lanes 1-9); in a time course, product $A$ is detectable after 1-2 min of incubation, whereas product $\mathrm{B}$ appears after $\sim 5 \mathrm{~min}$. U15A* RNA accumulates later, after $\sim 20 \mathrm{~min}$. The appearance of products is abolished when extract is omitted (lane 11) and is diminished by increasing amounts of EDTA (lanes 13,14). Likewise, when ATP is omitted from the reaction (lanes 18,21), the formation of product $\mathrm{A}$, but not $\mathrm{B}$, is markedly reduced and $\mathrm{U} 15 \mathrm{~A}^{*}$ is not generated. The material running in the position of band $A$ under these conditions may represent a nonspecific degradation product, because overall degradation increases when ATP is omitted from the reaction (lanes 18,21). Formation of U15A* cannot be restored by substitution of ATP with the nonhydrolyzable ATP analogs, AMPCPP, AMPPCP, or AMPPNP, whereas a trace amount of $\mathrm{U}_{15 \mathrm{~A}^{*}}$ is formed in the presence of GTP, CTP, or UTP. Some processing is also observed when the poorly hydrolyzable ATP analog, ATP $\gamma \mathrm{S}$, or dATP, is used for the reaction (data not shown). Without ATP, band B becomes tighter, indicating some trimming of either the substrate or product $B$. This effect can be ascribed to the rise in effective $\mathrm{Mg}^{2+}$ concentration when ATP is removed from the reaction because the same tightening of band $\mathrm{B}$ occurs when $\mathrm{MgCl}_{2}$ concentration is increased (lane 15). We conclude that processing at both ends of U15A RNA can be achieved in vitro by activities dependent on $\mathrm{Mg}^{+2}$ and (for $3^{\prime}$ cleavage) ATP.

\section{Mapping the ends of in vitro-processed U15A RNA}

We gel-purified each processed product and mapped its $5^{\prime}$ end by primer extension using the U15A(28-44) primer (Fig. 7). The 5' ends of both U15A* (lane 7) and product $B$ (lane 9) correspond exactly to the $5^{\prime}$ end of endogenous human U15A RNA (lane 6). Product A retains the same end as the processing substrate (lane 11). To show that both U15A* and product B possess $5^{\prime}$-monophosphates, we performed two-dimensional TLC analysis of their complete RNase T2 digestion products (Fig. 7B). In addition to 3'-nucleoside monophosphates, both RNAs yielded a radiolabeled $\mathrm{pCp}$ (upper panels) when the processing substrate was labeled with $\left[\alpha-{ }^{32} \mathrm{P}\right] \mathrm{CTP}$ (Fig. 7B) but not when the substrate was labeled with $\left[\alpha-{ }^{32} \mathrm{P}\right] \mathrm{GTP}$ (data not shown). Formation of the pCp spots was abolished when isolated RNAs were treated with calf intestinal phosphatase $(\mathrm{CIP})$ prior to RNase T2 digestion (lower panels). These analyses demonstrate that both U15A* and product B possess $5^{\prime}$-monophosphates followed by a $C$ residue, as does endogenous U15A RNA.

To map the $3^{\prime}$ ends of the processed products, we performed nuclease $S 1$ protection analyses on gel-purified $\mathrm{U}_{15 \mathrm{~A}^{*}}$ and products $\mathrm{A}$ and $\mathrm{B}$ using a $3^{\prime}$-end labeled DNA probe complementary to the last 91 nucleotides of U15A RNA and 68 nucleotides of its 3 '-flanking sequence (Fig. $8)$. Whereas endogenous U15A yields a relatively discrete band (lane 3), both U15A* and product A produce a het- 


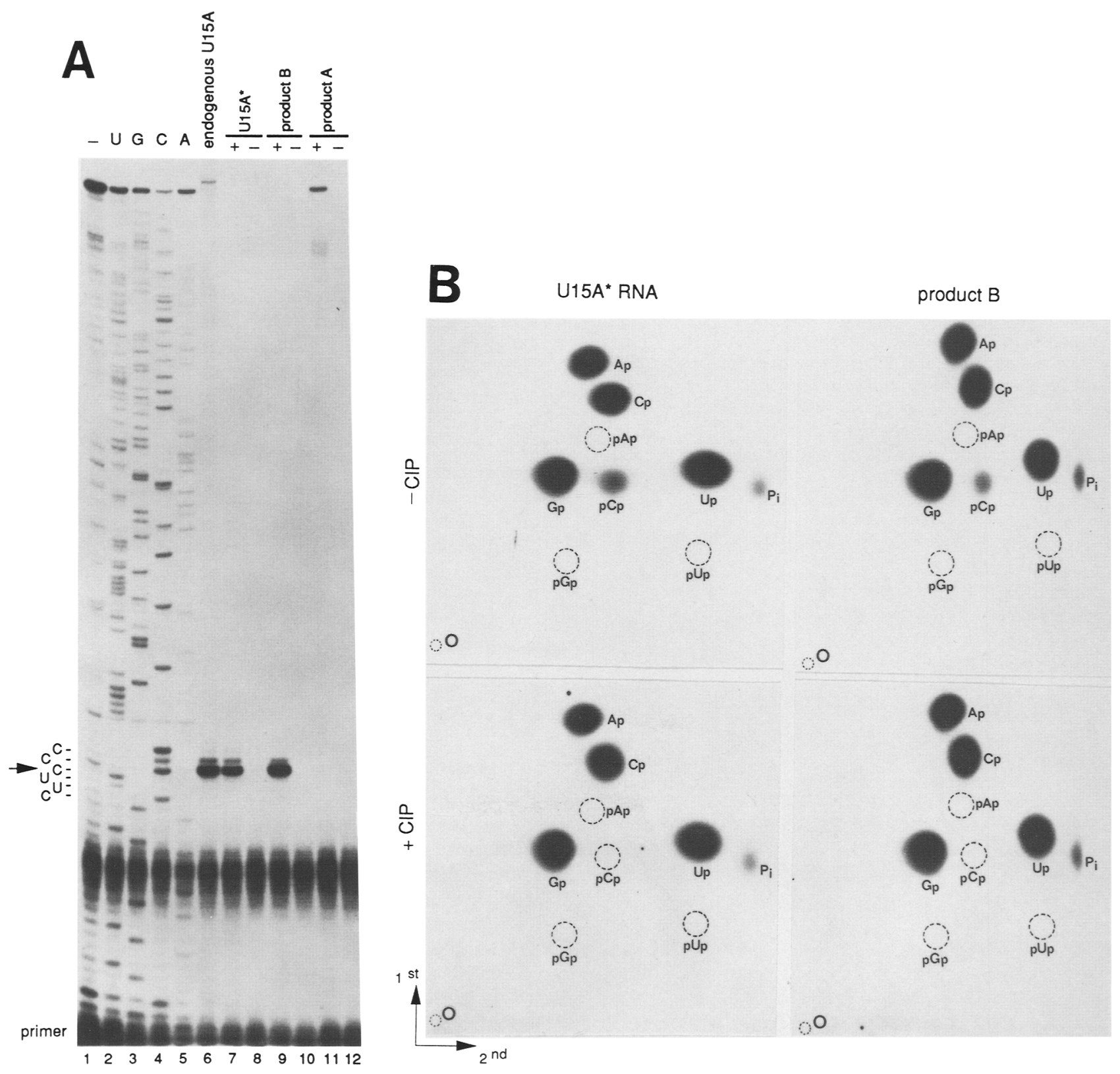

Figure 7. Mapping the $5^{\prime}$ end of in vitro-processed U15A RNA. (A) Gel-purified U15A* RNA and processing products B and A (see Fig. 6) were reverse transcribed using the U15A(28-44) primer (lanes 7,9, and 11, respectively). To control for nonspecific priming from other RNAs present in the S-100 extract, reverse transcription was also performed on RNA comigrating with U15 * and products $B$ and $A$, but isolated from a processing reaction that did not contain the processing substrate (lanes 8,10 , and 12 , respectively). The $5^{\prime}$ end of the endogenous HeLa U15A RNA was determined by primer extension performed on total nuclear RNA (lane 6). Primer extension products were separated on an $8 \%$ denaturing polyacrylamide gel alongside dideoxynucleotide sequencing ladders (lanes $1-5)$ generated by reverse transcription of the processing substrate. The arrow indicates the primer extension product corresponding to the $5^{\prime}$ end of U15A, U15A*, and processing product B. The faint band above the product in lanes 6,7 , and 9 does not appear reproducibly. $(B) 5^{\prime}$-End group analysis of $U 15 A^{\star}$ and processing product B. Gel-purified U15A* and band B generated by processing of the $-156 / 220$ substrate uniformly labeled with $\left[\alpha_{-}{ }^{32} \mathrm{P}\right] \mathrm{CTP}$ were treated with CIP (lower panels) or buffer alone (upper panels), then phenol extracted, ethanol precipitated, and digested with RNase T2. The resulting nucleotides were analyzed by two-dimensional TLC on cellulose plates in solvent A and B (see Materials and methods) in the first and second dimensions, respectively. The positions of unlabeled pAp, pCp, pGp, and pUp added as markers are indicated by broken circles. $(O)$ The chromatography origin.

erogeneous pattern (Fig. 8, lanes 4,6; data not shown). The two major upper bands in the case of U15A* (lane 4) suggest that the major species generated in vitro are $\sim 5$ nucleotides longer than endogenous U15A RNA (see Fig. 6 , lanes 22,23). The same is true of product A (lane 6). Product B protects the entire length of the probe (lane 5), 


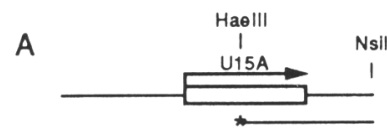

B
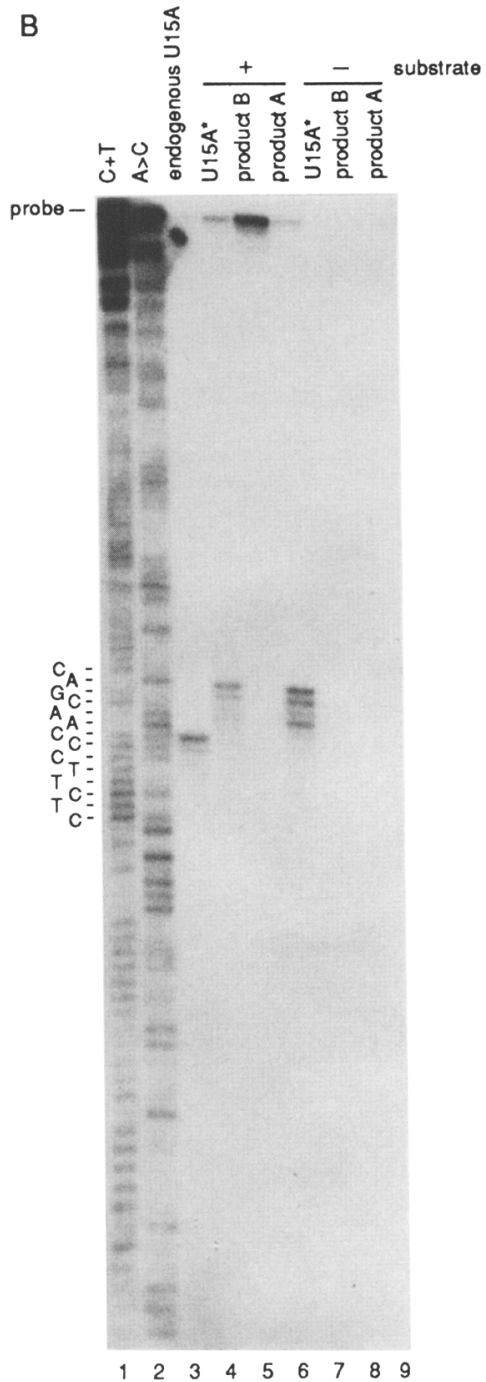

Figure 8. S1 nuclease analysis of the $3^{\prime}$ end of in vitro-processed U15A RNA. (A) The DNA probe used for S1 nuclease mapping. (B) Gel-purified U15A* and processing products $B$ and A (see Fig. 6) were hybridized to the $3^{\prime}$-end-labeled probe and digested with S1 nuclease; the protected DNA fragments were separated on an $8 \%$ denaturing polyacrylamide gel (lanes 4,5 , and 6 , respectively) alongside $\mathrm{C}+\mathrm{T}$ (lane 1 ) and $\mathrm{A}>\mathrm{C}$ (lane 2) sequencing ladders of the probe (Maxam and Gilbert 1977). To control for nonspecific protection by other RNAs present in the S-100 extract, S1 nuclease analyses were also performed on

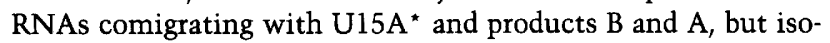
lated from a processing reaction that did not contain the processing substrate (lanes 7, 8, and 9, respectively). The S1 protection pattern by endogenous HeLa U15A RNA was obtained with total nuclear RNA (lane 3).

showing that its $3^{\prime}$ end corresponds to that of the substrate, as expected.

\section{Discussion}

A new structural motif for nucleolar snRNAs

Immunoprecipitation of HeLa cell small RNAs with anti-fibrillarin antibodies previously revealed, in addition to the $\mathrm{m}_{3} \mathrm{G}$-capped RNAs U3, U8, and U13, at least two other small RNAs initially designated RNAs $X$ and Y (Tyc and Steitz 1989). Our sequence analysis of RNA X has revealed two variants, now called U15A and U15B (Fig. 1A), which contain three homologous regions. Two of these are located at the ends of the RNAs and form a characteristic stem/loop/stem structure (Fig. 1A) that is also found in all known U3 snRNAs (Fig. 1B; for other U3 sequences, see Parker and Steitz 1987; Porter et al. 1988; Marshallsay et al. 1992 and references therein). Mammalian U14 and RNA Y can also be folded into similar structures (this paper). The $3^{\prime}$ side of the internal loop is occupied in every case by a highly conserved sequence called box D, noted previously in all known U3, U8, U13, and U14 RNAs (Hughes et al. 1987; Tyc and Steitz 1989; Jarmolowski et al. 1990; Liu and Maxwell 1990 ), as well as in RNA Y (this paper) and yeast snR190 (Zagorski et al. 1988). At present, the function of box D is not known. The $5^{\prime}$ side of the loop contains a sequence PuUGA ${ }^{\mathrm{A}}{ }_{\mathrm{A}} \mathrm{GA}$, which we designate box $\mathrm{C}^{\prime}$ because it resembles box $\mathrm{C}$ (mammalian consensus sequence is UGAUGAUPyG) of U3, U8, and U13 RNAs (Tyc and Steitz 1989). Note that U3 therefore possesses both box $\mathrm{C}$ and $\mathrm{C}^{\prime}$. The proposed secondary structures of human U8 and U13 (Tyc and Steitz 1989) predict that boxes C and $\mathrm{D}$ are positioned in close proximity to each other also in these RNAs.

Two lines of evidence suggest that the stem/loop/ stem motif of U15 and other nucleolar snRNAs binds a protein, or proteins. First, both strands of the internal loop are protected from RNase degradation in the native mammalian U3 RNP particle (Parker and Steitz 1987; Kass et al. 1990), whereas box $\mathrm{C}^{\prime}$ is available for oligonucleotide-directed $\mathrm{RNaseH}$ degradation in naked U3 RNA (Tyc and Steitz 1992). Second, mutations in both box $C^{\prime}$ (called box $C$ in the cited papers) and $D$ cause severe underaccumulation of yeast U14 RNA (Jarmolowski et al. 1990; Huang et al. 1992). The only wellcharacterized protein common to these nucleolar snRNPs is fibrillarin. The binding of fibrillarin to U3 RNA in vitro in whole-cell extracts (Baserga et al. 1991), as well as in vivo in Xenopus oocytes (Baserga et al. 1992), has been demonstrated to require an intact box C. In addition to box $\mathrm{C}$, however, box $\mathrm{C}^{\prime}$ is also retrieved by anti-fibrillarin antibody after RNase $\mathrm{T} 1$ or RNase A digestion of the native U3 RNP (Parker and Steitz 1987). We suggest that box $\mathrm{C}^{\prime}$ also interacts with fibrillarin, although the interaction may well be indirect. Recent studies by Huang et al. (1992) suggest that box D may also be required for fibrillarin binding to yeast U14 RNA. Like the stem/loop/stem motif, the fibrillarin protein is highly conserved in evolution; human and yeast fibrillarin are $70 \%$ identical, and the human protein can functionally complement a yeast fibrillarin mutant (Jansen et al. 1991). Alternatively, another protein common to the 
family of fibrillarin-associated nucleolar snRNPs, might bind to box $\mathrm{C}^{\prime}$ (and/or box D) within the stem/loop/ stem motif.

The structure of the terminal stem of the stem/loop/ stem motif, but not its sequence, is needed for trimethylation of U3 RNA and nuclear import of the U3 snRNP particle (Baserga et al. 1992). In U14, U15, and RNA Y, which do not possess $m_{3} G$ caps and seem to follow different pathways of biogenesis compared with U3, this motif may alternatively play a role in the processing of the termini and later in stabilizing the mature RNAs. Accordingly, the terminal stem is important for accumulation of yeast U14 RNA (Huang et al. 1992).

In addition to the stem/loop/stem motif, U15A and U15B share another conserved sequence in the middle of the molecules. It folds into a characteristic triple stemloop structure (Fig. 1A) and may be involved in a U15specific function because it is unique to U15A and B RNAs. At present, the cellular role of U15 RNA is not known. The fact that it is located in the nucleolus and shares many characteristics with U14, which functions in pre-rRNA processing in yeast ( $\mathrm{Li}$ et al. 1990), prompts us to speculate that U15 also acts in rRNA maturation.

\section{The gene for U15A snRNA resides within the gene} for an unusual r-protein, $S 3$

Unexpectedly, the single-copy gene for human U15A RNA has been found to reside in the first intron of the r-protein S3-coding region. Protein S3 is of special interest for several reasons. First, it forms part of the domain on the ribosome where the initiation of translation occurs; it can be cross-linked to eukaryotic initiation factors eIF-2 (Westermann et al. 1979) and eIF-3 (Tolan et al. 1983), as well as to mRNA (Takahashi and Ogata 1981). Second, evidence is accumulating that S3 from both mammalian and Drosophila cells has AP endonuclease I activity (S. Linn, pers. comm.; M. Kelley, pers. comm.), which catalyzes incision on the $3^{\prime}$ side of AP sites in damaged DNA (Demple and Linn 1980; Kim and Linn 1988). AP endonuclease I has been defined as one of seven complementation groups for xeroderma pigmentosum, a disease characterized by hypersensitivity to UV irradiation (Kraemer et al. 1975; Kuhnlein et al. 1976).

A similar intron location has been observed for the mammalian U14 RNA gene; a perfect copy of the mouse U14 sequence is positioned within intron 5 of a constitutively expressed $h s c 70$ gene, and closely related sequences are present in introns 6 and 8 (Liu and Maxwell 1990). It is not known, however, whether the intron 6 and 8 genes are expressed. Another nucleolar snRNA, U17, is also intron encoded (Kiss and Filipowicz 1993).

At present, we do not know the genomic organization of the gene for U15B RNA. Southern blot analysis indicates that the U15B gene is also single copy (data not shown). It is conceivable that this RNA is encoded in yet another intron of the same S3 gene or, alternatively, in intron 1 of another S3 gene. The rat genome contains 8-10 regions that hybridize to an S3 cDNA probe /Chan et al. 1990), but it is not known how many genes are functional. Many mammalian r-protein genes are present in multiple copies; however, no example is known where more than one gene is functional (for review, see Wool et al. 1990).

\section{Generation of U15A RNA by processing of intron sequences}

The existence of $5^{\prime}$-monophosphates on U15 and RNA Y indicates that at least their $5^{\prime}$ termini are produced by the processing of longer transcripts. Several additional lines of evidence are consistent with U15A RNA being produced from the same transcript as S3 mRNA: (1) U15A RNA is encoded on the same strand as S3 mRNA; (2) its coding region and flanking sequences do not possess any known promoter and terminator signals for nuclear RNA polymerases; and finally (3) fragments of S3 intron 1 are processed in cell-free extracts to yield U15A* RNA, whose $5^{\prime}$ end corresponds precisely to the $5^{\prime}$ end of endogenous U15A, whereas its $3^{\prime}$ end is $\sim 5$ nucleotides longer (Fig. 6). Although our findings do not formally exclude the possibility that in vivo U15A is transcribed either directly or as a longer precursor from a novel set of transcription signals, the simplest interpretation is that U15A is generated from S3 intron RNA.

Incubation of S3 intron 1 transcripts in L1210 cell S-100 extracts results in formation of three products (Fig. 6 ). The lengths of these products and mapping of their $5^{\prime}$ (Fig. 7) and 3' (Fig. 8) ends demonstrate that the shortest (band C) is U15A RNA with a short extension at the $3^{\prime}$ end $\left(U 15 A^{*}\right)$. The two longer products correspond to U15A* plus the $5^{\prime}$-flanking sequence (band A) and U15A plus the $3^{\prime}$-flanking sequence (band $B$ ). The cutoff $5^{\prime}$ and $3^{\prime}$ sequences are not detectable (Fig. 6 and data not shown), suggesting that either the cleavages leading to $\mathrm{U}^{15 \mathrm{~A}^{*}}$ formation are exonucleolytic or, alternatively, the cutoff fragments are rapidly degraded in vitro. Rapid degradation of cutoff flanking sequences has been observed in other in vitro systems, for example, mRNA polyadenylation (Moore and Sharp 1985), histone mRNA $3^{\prime}$-end formation (Gick et al. 1986) and 5' ETS rRNA processing (Kass et al. 1990). The formation of three products from intron 1 transcripts shows that processing at each of the U15A* ends can occur independently. The rapid appearance of bands $A$ and $B$ compared with band $C$ (Fig. 6) indicates that products $A$ and $B$ may be obligate intermediates for $\mathrm{U} 15 \mathrm{~A}^{\star}$ formation. If so, the relative abundance of these products suggests that $3^{\prime}$ - rather than 5 '-end formation is a rate-limiting step during maturation of U15A* RNA. This becomes clear when $2 \mathrm{~mm}$ EDTA is added to the processing reaction: Formation of U15A* RNA and of product A are only slightly inhibited $(<50 \%)$, whereas formation of band $B$ is inhibited $>90 \%$ (Fig. 6, lane 14). Alternatively, bands A and B may be dead-end products with formation of the 5 ' end of U15A coupled directly to 3 '-end processing. Interestingly, the secondary structure model predicts that the ends of U15A RNA are in close proximity (see Fig. 1A). Moreover, the terminal 4-bp stem can be extended in the precursor to $8 \mathrm{bp}$ (Fig. 9). A similar situation exists in the 


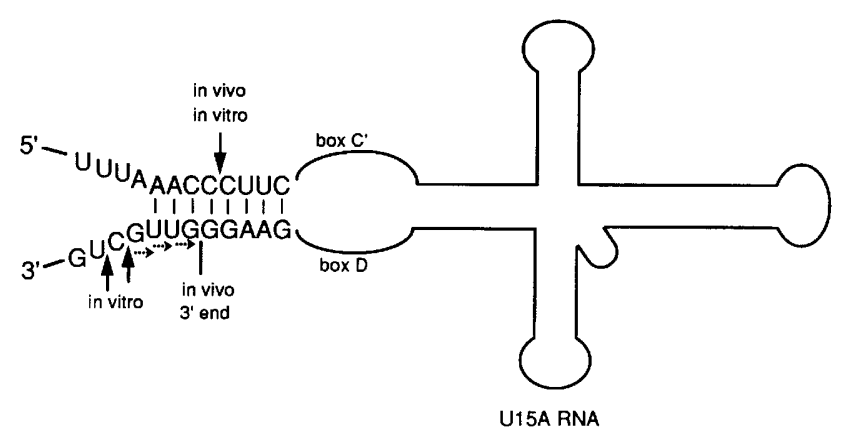

Figure 9. Possible structure of the processing sites in the U15A precursor. The 4-bp terminal stem of mature U15A RNA can be extended to an 8-bp stem in the U15A precursor RNA. Solid arrows indicate observed processing sites. The dashed arrows indicate exonucleolytic trimming of the $3^{\prime}$ extension deduced to be required to form the $3^{\prime}$ end of mature U15A.

case of U14 RNA (Liu and Maxwell 1990), where the ability of in vitro-synthesized $h s c 70$ intron transcripts to be processed in Xenopus oocytes (Leverette et al. 1992) suggests that U14 is excised by similar mechanism.

Interestingly, a similar arrangement of the $5^{\prime}$ - and $3^{\prime}$ processing sites also occurs in the Bacillus subtilis precursor to 5S rRNA, where an enzyme called endonuclease M5 performs both cleavages (Sogin et al. 1977; Pace et al. 1984). The U15A 3' end appears to be formed in a two-step reaction. First, ATP-dependent processing yields a U15A precursor with a few additional nucleotides, which are then trimmed to generate mature U15A RNA. At present, the mode of the ATP action is not known. Conceivably, some ATP-dependent chaperone-like function may be required for assembly of U15A with proteins, which might direct the processing reaction.

Intron location: a common regulatory scheme for coordinate synthesis of nucleolar proteins and small RNAs?

Because protein $\mathrm{S} 3$ and probably U15A RNA function in ribosome production, processing of S3 mRNA and U15A RNA from the same primary transcript could represent a mechanism for coordinate expression of these two nucleolar components. In all organisms, expression of rRNA and r-proteins is tightly controlled to balance in the amounts of ribosomal components (for review, see Nomura et al. 1984; Amaldi et al. 1989; Warner 1989). In prokaryotes, the production of r-proteins is controlled by feedback mechanisms operating at the translational level (for review, see Nomura et al. 1984). In eukaryotes, where translation of $\mathrm{r}$-proteins and ribosome assembly take place in different cellular compartments, regulation of r-protein synthesis can occur at the level of mRNA processing. This is the case for yeast r-protein L32 (Eng and Warner 1991), which binds to a structure in its premRNA that sequesters the $5^{\prime}$ splice site and thus prevents excision of the intron. R-protein L1 in Xenopus has also been implicated in regulating the splicing of its own pre-mRNA (for review, see Amaldi et al. 1989). The biosynthesis of S3 mRNA and U15A snRNA from the same primary transcript could represent yet another type of regulatory mechanism operating at the level of RNA processing. Competition between the splicing of intron 1 , leading to mRNA formation, and cleavage of intron 1 to yield U15A would be mutually exclusive events unless U15A can be processed from the excised intron. The resulting pre-mRNA destruction would maintain balanced production of S3 mRNA and U15A snRNA.

Positioning of small nucleolar RNAs in introns of important nucleolar proteins may in fact be a widespread, but previously unrecognized, regulatory strategy used by vertebrate cells. In addition to U14 and U15A, genes for other small RNAs may exist in introns of the frog r-protein L1 (Loreni et al. 1985; Cutruzzola et al. 1986) and the rodent nucleolin (Bourbon and Amalric 1990) genes . In each case, a conserved $\sim 70$ - to 100-nucleotide-long sequence is repeated in several introns. Some of these conserved regions possess sequences corresponding to boxes $C^{\prime}$ and $D$, as well as the potential for forming at least one stem of the stem/loop/stem motif /our observation). In the case of $\mathrm{r}$-protein $\mathrm{L} 1$, formation of a small RNA derived from the regulatory third intron has been observed in vivo in Xenopus oocytes (Fragapane et al. 1992; Prislei et al. 1992).

A pattern emerges from these examples. With the exception of hsc70, the genes containing intron-encoded snRNAs code for either components of the mature ribosome (proteins S3 and L1) or a protein that is involved in ribosome biogenesis [nucleolin (Herrera and Olson 1986; Jordan 1987; Kondo and Inouye 1992)]. Therefore, like the small RNAs, all of these proteins function, at least transiently, in the nucleolus. Even hsc 70 protein is located predominantly in the nucleolus after heat shock, where it apparently binds to partially assembled ribosomes and, together with hsp70, may help to repair damaged preribosomes (for review, see Pelham 1986; Gething and Sambrook 1992).

In the proposed coordinate expression of nucleolar proteins and small RNAs, the effector(s) might be fibrillarin or other protein(s), perhaps r-proteins themselves, that bind the snRNA portion of the intron. Interestingly, fibrillarin has recently been detected outside of the nucleolus in coiled bodies (Raska et al. 1991), nuclear organelles containing spliceosomal snRNPs, and other splicing factors (Carmo-Fonseca et al. 1992 and references therein). Moreover, the coiled bodies are often found associated with the nucleolus (Raska et al. 1990). Binding of fibrillarin to introns containing small RNA sequences would provide a rationale for the association of fibrillarin with components of the splicing machinery.

\section{Materials and methods}

\section{Oligonucleotides}

Oligonucleotides were synthesized by J. Flory (Yale University, New Haven, CT) on an Applied Biosystems synthesizer. The 
following deoxyoligonucleotides were used: X-15, CGCGTCGACGAAGTAATTTCCTAAAGATGACTTAG; X-16, CGCGAATTCGCAGCACAGAGTAGGCCACCT GG; U15-3', CTTCTCAGACAAATGCC; U15A(28-44), GAGAACATCCCCAAGTC; U15A(91-110), TACTTCAACCAGGGCTCTTT; U15A-10, CTTGGGGATGTTCTCTTTGCCAGGTGGCCTACTCTGTGCTGCGTTCTGTGG; U15A-11, GTCATCTTTAGGAAATTACTTCAACCAGGGCTCTTTAAACTGTGCCAC AGAACGCAGCAC; U15B(28-44), GCAGGACGTGACCTTTC; Y-3', TCCCTCAGACAGTTCCTTC; U3(64-79), GTGGTTTTCGGTGCTC; and U2(28-42); CAGATACTACACTTG. The biotinylated deoxyoligonucleotides had four [U15-3', $\left.\mathrm{U} 15 \mathrm{~B}(28-44), \mathrm{Y}-3^{\prime}\right]$ or two [U15A(91-110)] biotin residues attached to the $5^{\prime}$ end. Sequences of the primers used for PCR amplifications are indicated in Figure 5. The 2'-O-methyl RNA oligonucleotide U6d (BBBBAUCCUUGCGCAGGGGCCA, where $B$ stands for modified 2 '-deoxycytidine residues, which are sites for biotinylation) was synthesized from phosphoramidite monomers purchased from EMBL (Heidelberg, Germany) and biotinylated according to Sproat et al. (1989).

\section{Preparation of extracts and snRNP immunoprecipitation}

Preparation of HeLa cell extracts and immunoprecipitations were performed essentially as described (Steitz 1989) except that cells were sonicated in NET500 buffer $(50 \mathrm{~mm}$ Tris- $\mathrm{HCl}$ at $\mathrm{pH} 7.5,500 \mathrm{mM} \mathrm{NaCl}, 0.05 \% \mathrm{NP}-40$ ) or as otherwise stated. Sonication was performed five times for $30 \mathrm{sec}$ each with 30 -sec intervals on ice at a setting of 1.5 using a Branson microtip. Immunoprecipitations with monoclonal anti-fibrillarin antibody $72 \mathrm{~B}$ (generous gift from $\mathrm{M}$. Pollard and E. Tan, Scripps Clinic, La Jolla, CA) were carried out in NET500 or as stated otherwise, and the precipitates were washed in NET150 buffer (50 mM Tris $\mathrm{HCl}$ at $\mathrm{pH} 7.5,150 \mathrm{~mm} \mathrm{NaCl}, 0.05 \% \mathrm{NP}-40$ ).

\section{RNA sequencing}

Anti-fibrillarin-precipitated RNA was $3^{\prime}$-end-labeled with ${ }^{32} \mathrm{pCp}$ and T4 RNA ligase (Pharmacia) as described (England and Uhlenbeck 1978). After fractionation on $8 \%$ denaturing polyacrylamide gels, U15 and RNA Y were eluted and subjected to partial digestion with base-specific ribonucleases T1, U2, Phy $\mathrm{M}$, Bacillus cereus and CL3 (Pharmacia) (Donis-Keller at al. 1977; Donis-Keller 1980). Digestion products were fractionated on $20 \%$ denaturing polyacrylamide gels.

\section{Primer extension and cDNA sequencing}

Total cellular RNA was used as a source of templates for reverse transcription of U15 and Y RNAs except when stated otherwise. Primer hybridization, extension reactions and sequencing by the dideoxynuclotide method were performed as described (Parker and Steitz 1987). Full-length primer extension products were gel purified and sequenced by the chemical cleavage method (Maxam and Gilbert 1977). For mapping the 5' ends of in vitro-processing products, $\sim 10^{5} \mathrm{cpm}$ of U15A(28-44) primer (sp. act. $5 \times 10^{5} \mathrm{cpm} / \mathrm{ng}$ ) was hybridized to $2-4$ fmoles of RNA at $53^{\circ} \mathrm{C}$ for $30 \mathrm{~min}$, and extension was carried out as described (Parker and Steitz 1987).

\section{5 '-end RNA labeling}

Anti-fibrillarin-precipitated RNA was treated with CIP (Boehringer Mannheim) as described (Maniatis et al. 1982) except that incubation was carried out at $50^{\circ} \mathrm{C}$ for $30 \mathrm{~min}$. Phosphorylation of the $5^{\prime}$ end was performed as described (Maniatis et al.
1982). 5'-End capping was carried out in a $25-\mu l$ reaction containing either $5 \mu \mathrm{g}$ of $\mathrm{HeLa}$ nuclear RNA (from $10^{6}$ cells) or anti-fibrillarin-precipitated RNA (from $10^{7}$ cells), $50 \mathrm{mM}$ Tris$\mathrm{HCl}(\mathrm{pH} 7.8), 2 \mathrm{~mm} \mathrm{MgCl}, 6 \mathrm{~mm} \mathrm{KCl}, 2 \mathrm{~mm}$ DTT, $0.2 \mathrm{~mm}$ EDTA, $0.1 \mathrm{mg} / \mathrm{ml} \mathrm{BSA}, 30 \mu \mathrm{Ci}$ of $\left[\alpha^{-32} \mathrm{P}\right] \mathrm{GTP}$ (sp. act. 3000 $\mathrm{Ci} / \mathrm{mmole}$ ), and 2.5 units of vaccinia virus guanylyltransferase (GIBCO BRL). After labeling, the RNA was PCA (phenol/chloroform/iso-amylalcohol, $25: 25: 1)$ extracted, ethanol precipitated, and treated with $20 \mathrm{U} / \mathrm{ml}$ of DNase I (Promega) at $37^{\circ} \mathrm{C}$ for $10 \mathrm{~min}$ as indicated by the manufacturer. After a second PCA extraction and ethanol precipitation, the RNAs were separated on $8 \%$ denaturing polyacrylamide gels. The DNase I treatment markedly reduced nonspecific background during gel electrophoresis. Affinity selection of RNA using biotinylated DNA or 2'-O-methyl RNA oligonucleotides was carried out as described (Blencowe et al. 1989). The human U6 RNA was obtained by in vitro transcription of the pSP64 plasmid containing a U6 insert (generous gift from David Wassarman, Yale University, New Haven, CT) by use of T7 RNA polymerase (Pharmacia).

\section{Cell fractionation}

Fractionation of HeLa cells was performed as described (Tyc and Steitz 1989).

\section{Genomic DNA hybridization}

Thirty micrograms of HeLa cell genomic DNA or indicated amounts of plasmid pS3(51-47) DNA were digested with an appropriate restriction endonuclease, fractionated in a $0.9 \%$ agarose gel, and transferred onto nitrocellulose membrane (Schleicher \& Schuell). The plasmid DNA was fractionated in the presence of $0.5 \mu \mathrm{g}$ of 123-bp DNA ladder (GIBCO BRL) as a carrier. Prehybridization was carried out at $42^{\circ} \mathrm{C}$ for $3 \mathrm{hr}$ in $6 \times$ SSC, $50 \%$ formamide, $0.5 \%$ SDS, $5 \times$ Denhardt's solution $10.1 \%$ Ficoll, $0.1 \%$ polyvinylpyrrolidone, $0.1 \% \mathrm{BSA}$ ), and $0.1 \mathrm{mg} / \mathrm{ml}$ of sonicated salmon sperm DNA; $5 \times 10^{6} \mathrm{cpm}$ of a heat-denatured probe was then added and hybridization continued for $15 \mathrm{hr}$. Filters were washed first at room temperature for $15 \mathrm{~min}$ in $2 \times$ SSC and $0.5 \%$ SDS, then at $50^{\circ} \mathrm{C}$ for $1 \mathrm{hr}$ in $1 \times$ SSC and $0.5 \%$ SDS, and for $30 \mathrm{~min}$ in $0.1 \times$ SSC and $0.5 \%$ SDS.

The U15A probe was prepared as follows: $20 \mathrm{ng}$ each of oligonucleotide U15A-10 and U15A-11, whose 3'-terminal $16 \mathrm{nu}$ cleotides are complementary to each other, was annealed by heating for $5 \mathrm{~min}$ at $80^{\circ} \mathrm{C}$ and subsequent slow cooling over 30 min to room temperature; the single-stranded regions were then filled with 3 units of Klenow enzyme (generous gift from the N. Grindley laboratory, Yale University/ with $100 \mu \mathrm{Ci}$ each of ATP and GTP (sp. act. $3000 \mathrm{Ci} / \mathrm{mmole}$ ) as described (Maniatis et al. 1982). After a $30-\mathrm{min}$ incubation at room temperature, the reactions were chased with $50 \mathrm{~mm}$ each of unlabeled dATP and dGTP.

The intensities of the hybridization signals were quantitated on a Molecular Dynamics PhosphorImager. To determine the copy number of the U15A gene in the HeLa genome, the value of the average intensity of bands shown in lanes 1-5 of Figure 4 was divided by that of bands in lanes 6 and 7, which were normalized for $40 \mathrm{pg}$ of plasmid pS3(57-47).

\section{Cloning and sequencing of the U15A and S3 genes}

Total HeLa genomic DNA (4 $\mu \mathrm{g}$ ) was digested with either AluI, RsaI, or ApaLI, PCA extracted, ethanol precipitated, and circularized in $4 \mathrm{ml}$ with 20,000 units of DNA ligase (New England Biolabs) as described (Maniatis et al. 1982). The DNA was sub- 
sequently phenol extracted and divided into three parts. One part was used directly, and the two other parts were used after digestion with either DraI or BanII, for PCR amplification with primers X-15 and X-16, which contain HindIII and EcoRI sites at their 5' ends, respectively. The composition of PCR amplification reactions was as described (Toczyski and Steitz 1991), and the temperature cycles were as follows: $10 \mathrm{~min}$ at $94^{\circ} \mathrm{C} ; 30$ cycles of $2 \mathrm{~min}$ at $94^{\circ} \mathrm{C}, 3 \mathrm{~min}$ at $57.5^{\circ} \mathrm{C}$, and $6 \mathrm{~min}$ at $72^{\circ} \mathrm{C}$; and $6 \mathrm{~min}$ at $72^{\circ} \mathrm{C}$. PCR products were checked for U15A sequences by Southern analysis (Maniatis et al. 1982) using the $5^{\prime}$-endlabeled U15A(28-44) oligonucleotide as a probe. The hybridization-positive PCR products were digested with EcoRI and HindIII, agarose gel purified, and cloned into an EcoRI/HindIII-digested pGEM $3 Z$ vector. Sequences of two clones named pU15A-AluI and pU15A-Rsal, originating from amplification of the AluI and RsaI digests, respectively, were determined.

To obtain clones pS3(15-38), pS3(50-47) and pS3(31-47), PCR amplifications were carried out as described above except that 1-2 $\mu \mathrm{g}$ of undigested DNA and appropriate primers were used. To obtain the pS3(51-47) clone, PCR cycles were as follows: 10 min at $94^{\circ} \mathrm{C} ; 30$ cycles of $40 \mathrm{sec}$ at $96^{\circ} \mathrm{C}, 45 \mathrm{sec}$ at $58^{\circ} \mathrm{C}$, and 2 $\min$ at $72^{\circ} \mathrm{C}$; and $6 \mathrm{~min}$ at $72^{\circ} \mathrm{C}$. The inserts were cloned into the SmaI site of the pGEM3Z vector. DNA sequencing was performed using a Sequenase kit (U.S. Biochemicals) according to the manufacturer's protocol.

\section{In vitro processing}

To obtain the $-847 /+460$ processing substrate, the pS3(51-47) plasmid was cut with HindIII and transcribed with T7 RNA polymerase (Pharmacia) in the presence of $\left[\alpha-{ }^{32} \mathrm{P}\right] \mathrm{UTP}$ as described (Melton et al. 1984). To produce the $-156 /+220$ and $-59 / 220$ substrates, the pS3(50-47) and pS3(31-47) plasmids, respectively, were cut with $N$ siI and transcribed with SP6 RNA polymerase (Pharmacia) as above. The $-847 /+460$ substrate contains an additional 42 nucleotides, and the $-156 /+220$ and $-59 / 220$ substrates each contain 63 nucleotides at their $5^{\prime}$ ends, derived from the plasmid polylinker.

S-100 extract was prepared from mouse L1210 tissue culture cells as described (Miller and Sollner-Webb 1981). A typical 25$\mu l$ processing reaction contained $10 \mu \mathrm{l}$ of S-100 extract, $30 \mathrm{~mm}$ HEPES (pH 7.9), $160 \mathrm{~mm} \mathrm{KCl,} 2 \mathrm{~mm} \mathrm{MgCl}_{2}, 1.25 \mathrm{~mm}$ ATP, 0.18 mM EDTA, 0.8 mM DTT, 4\% (vol/vol) glycerol and 5-10 fmoles of substrate, unless otherwise indicated. After incubation for 60 min at $30^{\circ} \mathrm{C}, 200 \mu l$ of a solution containing $20 \mathrm{mM}$ Tris $\langle\mathrm{pH}$ 7.5 |, $75 \mathrm{~mm} \mathrm{NaCl}, 0.2 \%$ SDS, $5 \mathrm{~mm}$ EDTA, and $20 \mathrm{mg}$ of proteinase $\mathrm{K}$ (Beckman) was added, and the sample was digested for $15 \mathrm{~min}$ at $42^{\circ} \mathrm{C}$. RNA was PCA extracted, ethanol precipitated, and separated on $7 \%$ denaturing polyacrylamide gels.

\section{S1 nuclease analysis}

S1 nuclease protection assays were carried out according to Berk and Sharp (1977). To localize the $3^{\prime}$ ends of processing products, a 159-nucleotide HaeIII-Nsil fragment, labeled at the $3^{\prime}$ end (sp. act. $\left.10^{7} \mathrm{cpm} / \mu \mathrm{g}\right)$ with $\left[\alpha^{-32} \mathrm{P}\right] \mathrm{dGTP}$ and T4 DNA polymerase (Maniatis et al. 1982) was used. The probe (5000 cpm) was hybridized to 2-4 fmoles of gel-purified processing products or 5 $\mu \mathrm{g}$ of total HeLa nuclear RNA at $40^{\circ} \mathrm{C}$ for $3 \mathrm{hr}$ in the presence of $10 \mu \mathrm{g}$ of carrier RNA and digested with 550 units of nuclease $\mathrm{S} 1$ (Pharmacia) at $40^{\circ} \mathrm{C}$ for $1 \mathrm{hr}$. The nucleic acids were then PCA extracted, ethanol precipitated, and digested with $10 \mu \mathrm{g}$ of RNase A (Boehringer Mannheim) for $10 \mathrm{~min}$ at $37^{\circ} \mathrm{C}$. The protected DNA fragments were analyzed on $8 \%$ denaturing polyacrylamide gels.

\section{Analytical procedures}

Complete RNase T2 digestions and two-dimensional TLC were performed as described by Silberklang et al. (1979). Chromatography was carried out on cellulose plates in solvent $\mathrm{A}$ [isobutyric acid/ $/ \mathrm{NH}_{4} \mathrm{OH} / \mathrm{H}_{2} \mathrm{O} ; 577: 38: 385$ (vol)] in the first dimension and solvent $\mathrm{B}\left[t\right.$-butanol/concentrated $\mathrm{HCl} / \mathrm{H}_{2} \mathrm{O} ; 70: 15$ : 15 (voll) in the second dimension.

\section{Acknowledgments}

We are grateful to David Wassarman for suggesting inverted PCR for cloning the flanking sequences of the U15A gene and to other members of the Steitz laboratory for many helpful discussions. Wes Derrick (University of Colorado, Boulder) provided the pNp standards, and Magda Konarska (Rockefeller University) made many helpful suggestions on TLC analysis. We thank Witold Filipowicz, Ira Wool, Stu Linn, and Mark Kelley for communicating results prior to publication, and Susan Baserga, Brenda Peculis, and David Wassarman for critical reading of the manuscript. This work was supported in part by a grant GM26154 from the National Institutes of Health.

The publication costs of this article were defrayed in part by payment of page charges. This article must therefore be hereby marked "advertisement" in accordance with 18 USC section 1734 solely to indicate this fact.

\section{Note added in proof}

The sequence data for snRNA U15A, snRNA U15B, and ribosomal protein $\mathrm{S} 3$ gene have been submitted to the GenBank data library under accession numbers L15616, L15557, and L16016, respectively.

\section{References}

Amaldi, F., I. Bozzoni, E. Beccari, and P. Pirandrei-Amaldi. 1989. Expression of ribosomal protein genes and regulation of ribosome biosynthesis in Xenopus development. Trends Biochem. 14: 175-178.

Baserga, S.J., X.W. Yang, and J.A. Steitz. 1991. An intact box C sequence in the U3 snRNA is required for binding of fibrillarin, the protein common to the major family of nucleolar snRNPs. EMBO $/$. 10: 2645-2651.

Baserga, S.J., M. Gilmore-Hebert, and X.W. Yang. 1992. Distinct molecular signals for nuclear import of the nucleolar snRNA, U3. Genes \& Dev. 6: 1120-1130.

Berk, A.J. and P.A. Sharp. 1977. Sizing and mapping of early adenovirus mRNAs by gel electrophoresis of S1 endonuclease-digested hybrids. Cell 12: 721-732.

Blencowe, B.J., B.S. Sproat, U. Ryder, S. Barabino, and A.I. Lamond. 1989. Antisense probing of the human U4/U6 snRNP with biotinylated 2'-OMe RNA oligonucleotides. Cell 59: 531-539.

Bourbon, H.-M. and F. Amalric. 1990. Nucleolin gene organization in rodents: highly conserved sequences within three of the 13 introns. Gene 88: 187-196.

Carmo-Fonseca, M., R. Pepperkok, M.T. Carvalho, and A.I. Lamond. 1992. Transcription-dependent colocalization of the $\mathrm{U} 1, \mathrm{U} 2, \mathrm{U} 4 / \mathrm{U} 6$ and $\mathrm{U} 5$ snRNPs in coiled bodies. I. Cell Biol. 117: $1-14$.

Chan, Y.-L., K.R.G. Devi, J. Olvera, and I.G. Wool. 1990. The primary structure of rat ribosomal protein S3. Arch. Biochem. Biophys. 283: 546-550.

Cutruzzola, F., F. Loreni, and I. Bozzoni. 1986. Complementar- 
ity of conserved sequence elements present in $28 \mathrm{~S}$ ribosomal protein genes of Xenopus laevis and Xenopus tropicalis. Gene 49: 371-376.

Dahlberg, J.E. and E. Lund. 1988. The genes and transcription of the major small nuclear RNAs. In Structure and functions of major and minor small nuclear ribonucleoprotein particles (ed. M.L.Birnstiel), pp. 38-70. Springer-Verlag, Berlin, Germany.

Demple, B. and S. Linn. 1980. DNA N-glycosylases and UV repair. Nature 287: 203-208.

Dignam, J.D., R.M. Lebovitz, and R.G. Roeder. 1983. Accurate transcription initiation by RNA polymerase II in a soluble extract from isolated mammalian nuclei. Nucleic Acids Res. 11: $1475-1489$.

Donis-Keller, H. 1980. Phy M: an RNase activity specific for U and $\mathrm{A}$ residues useful in RNA sequence analysis. Nucleic Acids Res. 8: 3133-3142.

Donis-Keller, H., A.M. Maxam, and W. Gilbert. 1977. Mapping adenines, guanines, and pyrimidines in RNA. Nucleic Acids Res. 4: 2527-2538.

Eng, F.J. and J.R. Warner. 1991. Structural basis for the regulation of splicing of yeast messenger RNA. Cell 65: 1-20.

England, T.E. and O.C. Uhlenbeck. 1978. 3'-terminal labelling of RNA with T4 RNA ligase. Nature 275: 560-561.

Fragapane, P., E. Caffarelli, M. Lener, S. Prislei, B. Santoro, and I. Bozzoni. 1992. Identification of the sequences responsible for the splicing phenotype of the regulatory intron of the L1 ribosomal protein gene of Xenopus laevis. Mol. Cell. Biol. 12: $1117-1125$.

Gething, M.-J. and J. Sambrook. 1992. Protein folding in the cell. Nature 355: 33-45.

Gick, O., A. Kramer, W. Keller, and M.L. Birnstiel. 1986. Generation of histone mRNA 3 ' ends by endonucleolytic cleavage of the pre-mRNA in a snRNP-dependent in vitro reaction. $E M B O$ /. 5: 1319-1326.

Hartshorne, T. and N. Agabian. 1993. RNA B is the major nucleolar trimethylguanosine-capped small nuclear RNA associated with fibrillarin and pre-rRNAs in Trypanosoma brucei. Mol. Cell. Biol. 13: 144-154.

Hatlen, L.E., F. Amaldi, and G. Attardi. 1969. Oligonucleotide pattern after pancreatic ribonuclease digestion and the $3^{\prime}$ and 5 ' termini of $5 \mathrm{~S}$ ribonucleic acid from HeLa cells. Biochemistry 8: 4989-5005.

Herrera, A.H. and M.O.J. Olson. 1986. Association of protein C23 with rapidly labeled nucleolar RNA. Biochemistry 25: 6258-6263.

Huang, G., A. Jarmolowski, J.C.R. Struck, and M.J. Fournier. 1992. Accumulation of U14 small nuclear RNA in Saccharomyces cerevisiae requires box $\mathrm{C}$, box $\mathrm{D}$, and a $5^{\prime}, 3^{\prime}$ terminal stem. Mol. Cell. Biol. 12: 4456-4463.

Hughes, J.M.X. and M. Ares, Jr. 1991. Depletion of U3 small nucleolar RNA inhibits cleavage in the $5^{\prime}$ external transcribed spacer of yeast pre-ribosomal RNA and prevents formation of 18S ribosomal RNA. EMBO J. 10: 4231-4239.

Hughes, J.M.X., D.A.M. Konings, and G. Cesareni. 1987. The yeast homologue of U3 snRNA. EMBO I. 6: 2145-2155.

Jansen, R.P., E.C. Hurt, H. Kern, H. Lehtonen, M. Carmo-Fonseca, B. Lapeyre, and D. Tollervey. 1991. Evolutionary conservation of the human nucleolar protein fibrillarin and its functional expression in yeast. J. Cell Biol. 113: 715-729.

Jarmolowski, A., J. Zagorski, H.V. Li, and M.J. Fournier. 1990. Identification of essential elements in U14 RNA of Saccharomyces cerevisiae. EMBO I. 9: 4503-4509.

Jordan, G. 1987. At the heart of the nucleolus. Nature 329: 489490.

Kass, S., K. Tyc, J.A. Steitz, and B. Sollner-Webb. 1990. The U3 small nucleolar ribonucleoprotein functions in the first step of pre-ribosomal RNA processing. Cell 60: 897-908.

Kim, J. and S. Linn. 1988. The mechanisms of action of E. coli endonuclease III and T4 UV endonuclease (endonuclease V) at AP sites. Nucleic Acids Res. 16: 1135-1141.

Kiss, T. and W. Filipowicz. 1993. Small nucleolar RNAs encoded by introns of the human cell cycle regulatory gene RCC1. EMBO I. (in press).

Kondo, K. and M. Inouye. 1992. Yeast NSRl protein that has structural similarity to mammalian nucleolin is involved in pre-rRNA processing. $J$. Biol. Chem. 267: 16252-16258.

Kraemer, K.H., E.A. de Weerd-Kastelein, J.H. Robbins, W. Keijzer, S.F. Barret, R.A. Petinga, and D. Bootsma. 1975. Five complementation groups in xeroderma pigmentosum. $\mathrm{Mu}$ tat. Res. 33: 327-340.

Kuhnlein, U., E.E. Penhoet, and S. Linn. 1976. An altered apurinic DNA endonuclease activity in group $A$ and group D xeroderma pigmentosum fibroblasts. Proc. Natl. Acad. Sci. 73: $1169-1173$.

Kunkel, G. 1991. RNA polymerase III transcription of genes that lack internal control regions. Biochem. Biophys. Acta 1088: 1-9.

Leverette, R.D., M.T. Andrews, and E.S. Maxwell. 1992. Mouse U14 snRNA is a processed intron of the cognate hsc70 heat shock pre-messenger RNA. Cell 71: 1215-1221.

Li, H.V., J. Zagorski, and M.J. Fournier. 1990. Depletion of U14 small nuclear RNA (snR128) disrupts production of $18 \mathrm{~S}$ rRNA in Saccharomyces cerevisiae. Mol. Cell. Biol. 10: 1145-1152.

Lischwe, M.A., R.L. Ochs, R. Reddy, R.G. Cook, L.C. Yeoman, E.M. Tan, M. Reichlin, and H. Busch. 1985. Purification and partial characterization of a nucleolar scleroderma antigen $\left\langle\mathrm{M}_{\mathrm{r}}=34,000\right.$; pI, 8.5) rich in $\mathrm{N}^{\mathrm{G}}, \mathrm{N}^{\mathrm{G}}$-dimethylarginine. $/$. Biol. Chem. 260: 14304-14310.

Liu, J. and E.S. Maxwell. 1990. Mouse U14 snRNA is encoded in an intron of the mouse cognate hsc70 heat shock gene. $\mathrm{Nu}$ cleic Acids Res. 18: 6565-6571.

Loreni, F., I. Ruberti, I. Bozzoni, P. Pierandrei-Amaldi, and F. Amaldi. 1985. Nucleotide sequence of the L1 ribosomal protein gene of Xenopus laevis: Remarkable sequence homology among introns. EMBO $J$. 4: 3483-3488.

Lürmann, R. 1988. snRNP proteins. In Structure and functions of major and minor small nuclear ribonucleoprotein particles. (ed. M.L. Birnstiel), pp. 71-99. Springer Verlag, Berlin, Germany.

Maniatis, T., E.F. Fritsch, and J. Sambrook. 1982. Molecular cloning: A laboratory manual. Cold Spring Harbor Laboratory, Cold Spring Harbor, New York.

Marshallsay, C., S. Connelly, and W. Filipowicz. 1992. Characterization of the U3 and U6 snRNA genes from wheat: U3 snRNA genes in monocot plants are transcribed by RNA polymerase III. Plant Mol. Biol. 19: 973-983.

Maxam, A. and W. Gilbert. 1977. A new method for sequencing DNA. Proc. Natl. Acad. Sci. 74: 560-564.

Maxwell, E.S. and T.E. Martin. 1986. A low-molecular-weight RNA from mouse ascites cells that hybridizes to both $18 \mathrm{~S}$ rRNA and mRNA sequences. Proc. Natl. Acad. Sci. 83: 7261-7265.

Melton, D.A., P.A. Krieg, M.R. Rebagliati, T. Maniatis, K. Zinn, and M.R. Green. 1984. Efficient in vitro synthesis of biologically active RNA and RNA hybridization probes from plasmids containing a bacteriophage SP6 promoter. Nucleic Acids Res. 12: 7035-7056.

Miller, K.G. and B. Sollner-Webb. 1981. Transcription of mouse rRNA genes by RNA polymerase I: in vitro and in vivo initiation and processing sites. Cell 27: 165-174. 
Moore, C.L. and P.A. Sharp. 1985. Accurate cleavage and polyadenylation of exogenous RNA substrate. Cell 41: 845-855.

Nomura, M., R. Gourse, and G. Baughman. 1984. Regulation of the synthesis of ribosomes and ribosomal components. Annu. Rev. Biochem. 53: 75-117.

Ochs, R.L., M.A. Lischwe, W.H. Spohn, and H. Busch. 1985. Fibrillarin: A new protein of the nucleolus identified by autoimmune sera. Biol. Cell 54: 123-134.

Pace, B., D.A. Stahl, and N.R. Pace. 1984. The catalytic element of a ribosomal RNA-processing complex. J. Biol. Chem. 259: 11454-11458.

Parker, K.A. and J.A. Steitz. 1987. Structural analyses of the human U3 ribonucleoprotein particle reveal a conserved sequence available for base pairing with pre-rRNA. Mol. Cell. Biol. 7: 2899-2913.

Pelham, H.R.B. 1986. Speculations on the functions of the major heat shock and glucose-regulated proteins. Cell 46: 959-961.

Porter, G.L., P.J. Brennwald, K.A. Holm, and J.A. Wise. 1988. The sequence of U3 from Schizosaccharomyces pombi suggests structural divergence of this snRNA between metazoans and unicellular eukaryotes. Nucleic Acids Res. 16: 10131-10152.

Prislei, S., S. Sperandio, P. Fragapane, E. Caffarelli, C. Presutti, and I. Bozzoni. 1992. The mechanisms controlling ribosomal protein L1 pre-mRNA splicing are maintained in evolution and rely on conserved intron sequences. Nucleic Acids Res. 20: $4473-4479$.

Raska, I., R.L. Ochs, L.E.C. Andrade, E.K.L. Chan, R. Burlingame, C. Peebels, D. Gruol, and E.M. Tan. 1990. Association between the nucleolus and the coiled body. J. Struct. Biol. 104: 120-127.

Raska, I., L.E.C. Andrade, R.L. Ochs, E.K.L. Chan, C.-M. Chang, G. Roos, and E.M. Tan. 1991. Immunological and ultrastructural studies of the nuclear coiled body with autoimmune antibodies. Exp. Cell Res. 195: 27-37.

Reddy, R. and H. Busch. 1988. Small nuclear RNAs: RNA sequences, structure, and modification. In Structure and functions of major and minor small nuclear ribonucleoprotein particles (ed. M.L. Birnstiel), pp. 1-37. Springer-Verlag, Berlin, Germany.

Reddy, R., D. Henning, and H. Busch. 1979. Nucleotide sequences of nucleolar U3B RNA. J. Biol. Chem. 254: 1109711105.

Savino, R. and S.A. Gerbi. 1990. In vitro disruption of Xenopus U3 snRNA affects ribosomal RNA processing. EMBO J. 9: 2299-2308.

Shuman, S. and B. Moss. 1990. Purification and use of vaccinia virus messenger RNA capping enzyme. Methods Enzymol. 181: $170-180$.

Silberklang, M., A.M. Gillum, and U.L. RajBhandary. 1979. Use of in vitro ${ }^{32} \mathrm{P}$ labeling in the sequence analysis of nonradioactive tRNAs. Methods Enzymol. 59: 58-109.

Sogin, M.L., B. Pace, and N.R. Pace. 1977. Partial purification and properties of a ribosomal RNA maturation endonuclease from Bacillus subtilis. J. Biol. Chem. 252: 1350-1357.

Sproat, B.C., A.I. Lamond, B. Beijer, P. Neuner, and U. Ryder. 1989. Highly efficient chemical synthesis of $2^{\prime}$-O-methyloligoribonucleotides and tetrabiotinylated derivatives; novel probes that are resistant to degradation by RNA or DNA specific nucleases. Nucleic Acids Res. 17: 3373-3384.

Steitz, J.A. 1989. Immunoprecipitation of ribonucleoproteins using autoantibodies. Methods Enzymol. 180: 468-481.

Takahashi, Y. and K. Ogata. 1981. Ribosomal proteins crosslinked to natural mRNA by UV irradiation of rat liver polysomes. I. Biochem. (Tokyo) 90: 1549-1552.

Toczyski, D.P.W. and J.A. Steitz. 1991. EAP, a highly conserved cellular protein associated with Epstein-Barr virus small RNAs (EBERs). EMBO $J$. 10: 459-466.

Tolan, D.R., J.W.B. Hershey, and R.T. Traut. 1983. Crosslinking of eukaryotic initiation factor eIF3 to the 40 S ribosomal subunit from rabbit reticulocytes. Biochemie 65: 427-436.

Triglia, T., M.G. Peterson, and D.J. Kemp. 1988. A procedure for in vitro amplification of DNA segments that lie outside the boundaries of known sequences. Nucleic Acids Res. 16: 8186.

Tyc, K. and J.A. Steitz. 1989. U3, U8 and U13 comprise a new class of mammalian snRNPs localized in the cell nucleolus. EMBO I. 8: 3113-3119.

. 1992. A new interaction between the mouse 5 ' external transcribed spacer of pre-rRNA and U3 snRNA detected by psoralen crosslinking. Nucleic Acids Res. 20: 5375-5382.

Warner, J.R. 1989. Synthesis of ribosomes in Saccharomyces cerevisiae. Microbiol. Rev. 53: 256-271.

Westermann, P., W. Heumann, U.A. Bommer, H. Bielka, O. Nygard, and T. Hultin. 1979. Crosslinking of initiation factor eIF-2 to proteins of the small subunit of rat liver ribosomes. FEBS Lett. 97: 101-104.

Wool, I.G., Y. Endo, Y.-L. Chan, and A. Gluck. 1990. Structure, function, and evolution of mammalian ribosomes. In The ribosome. Structure, function, and evolution (ed. W.E. Hill, A. Dahlberg, R.A. Garrett, P.B. Moore, D. Schlessinger and J.R. Warner), pp. 203-214. American Society for Microbiology, Washington, D.C.

Zagorski, J., D. Tollervey, and M.J. Fournier. 1988. Characterization of an SNR gene locus in Saccharomyces cerevisiae that specifies both dispensible and essential small nuclear RNAs. Mol. Cell. Biol. 8: 3282-3290.

Zhang, X.T., Y.-M. Tan, and Y.H. Tan. 1990. Isolation of a cDNA encoding human 40S ribosomal protein S3. Nucleic Acids Res. 18: 6689. 


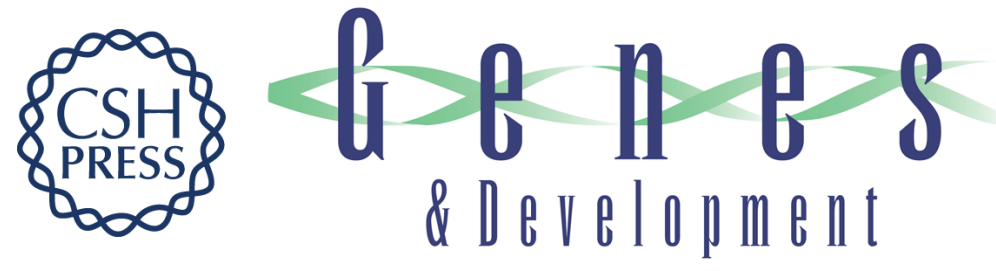

\section{A small nucleolar RNA is processed from an intron of the human gene encoding ribosomal protein S3.}

K T Tycowski, M D Shu and J A Steitz

Genes Dev. 1993, 7:

Access the most recent version at doi:10.1101/gad.7.7a.1176

References This article cites 70 articles, 18 of which can be accessed free at:

http://genesdev.cshlp.org/content/7/7a/1176.full.html\#ref-list-1

License

Email Alerting

Service

Receive free email alerts when new articles cite this article - sign up in the box at the top right corner of the article or click here.

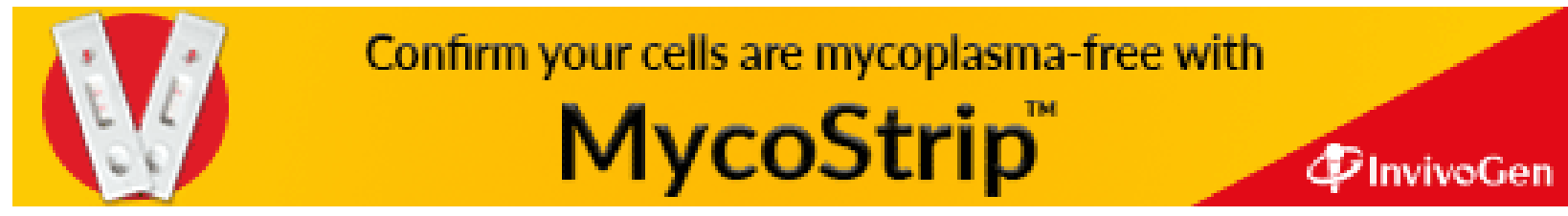

